\title{
miRNAs and Other Epigenetic Changes as Biomarkers in Triple Negative Breast Cancer
}

\author{
Andrea Mathe 1,2, Rodney J. Scott ${ }^{1,2,3}$ and Kelly A. Avery-Kiejda 1,2,* \\ Received: 22 September 2015; Accepted: 12 November 2015; Published: 30 November 2015 \\ Academic Editors: William Chi-shing Cho and Nalini Santanam \\ 1 Centre for Information Based Medicine, Hunter Medical Research Institute, Newcastle, NSW 2305, Australia; \\ andrea.mathe@uon.edu.au (A.M.); rodney.scott@newcastle.edu.au (R.J.S.) \\ 2 Priority Research Centre for Cancer, School of Biomedical Sciences and Pharmacy, Faculty of Health, \\ University of Newcastle, Newcastle, NSW 2308, Australia \\ 3 Hunter Area Pathology Service, Pathology North, John Hunter Hospital, Newcastle, NSW 2305, Australia \\ * Correspondence: Kelly.Kiejda@newcastle.edu.au; Tel.: +61-2-4042-0309; Fax: +61-2-4042-0031
}

\begin{abstract}
Triple negative breast cancer (TNBC) is characterised by the lack of receptors for estrogen (ER), progesterone (PR), and human epidermal growth factor 2 (HER2). Since it cannot be treated by current endocrine therapies which target these receptors and due to its aggressive nature, it has one of the worst prognoses of all breast cancer subtypes. The only treatments remain chemo- and/or radio-therapy and surgery and because of this, novel biomarkers or treatment targets are urgently required to improve disease outcomes. MicroRNAs represent an attractive candidate for targeted therapies against TNBC, due to their natural ability to act as antisense interactors and regulators of entire gene sets involved in malignancy and their superiority over mRNA profiling to accurately classify disease. Here we review the current knowledge regarding miRNAs as biomarkers in TNBC and their potential use as therapeutic targets in this disease. Further, we review other epigenetic changes and interactions of these changes with microRNAs in this breast cancer subtype, which may lead to the discovery of new treatment targets for TNBC.
\end{abstract}

Keywords: microRNA; triple negative breast cancer; DNA methylation

\section{Introduction}

Breast cancer has the highest incidence rate of all cancers in women worldwide [1]. It is a very heterogeneous disease and there are multiple ways by which to classify breast cancer into its subtypes. However, the primary diagnosis remains the histopathology report of the tumour which assesses the presence or absence of hormone receptors for estrogen (ER), progesterone (PR), and the human epidermal growth factor receptor-2 (HER2). The expression of these receptors is required to determine the patients' suitability for endocrine therapies such as Tamoxifen, Anastrozole, and Trastuzumab [2]. The majority of breast cancers are receptor positive (77\% [3]) and targeted treatment has proven efficacy. However, in the case of breast cancers that are negative for all three receptors (triple negative breast cancers, TNBC) there is, as yet, no targeted treatment available [4].

Further characteristics of the TNBC subtype are: germline BRCA1 mutations (10\%) [5], high mitotic counts and TP53 positivity [6]. The majority of TNBCs are from the basal-like subtype $(\sim 70 \%)[7]$ and express basal-type cytokeratin 5 and cytokeratin 6 , as well as high expression of the epidermal growth factor receptor (EGFR) [8]. Most TNBCs are classed as invasive ductal carcinomas, nevertheless a high proportion of other histology types are ER, PR, and HER2 negative including metaplastic carcinomas $[9,10]$ and apocrine carcinomas [11]. TNBC accounts for only $10 \%-17 \%$ of all breast cancer patients [12]. However, the disease is more common in young women (under 40 years of age/pre-menopausal [13]) and especially in African-Americans [12]. TNBC has a poor prognosis, 
associated with an increased number and earlier appearance of metastases (on average within the first 2.6 years after diagnosis [14]) compared to other breast cancer subtypes [6]. Within this review, we aim to provide an overview of the current knowledge regarding miRNAs and other epigenetic mechanisms that are involved in the development and progression of TNBC.

\section{Clinical Trials in TNBC}

The lack of hormone receptors and HER2 significantly reduces targeted treatment options for patients with TNBC. At the moment, the only available treatments are chemotherapy and surgery [12]. There are some trials with poly (ADP-ribose) polymerase (PARP) inhibitors, angiogenesis inhibitors, EGFR-targeted agents, src kinase inhibitors, and androgen receptor inhibitors [6,15], but none display significant improvements in all TNBC cases pointing to the heterogeneity of disease. PARP-inhibitors have shown the most encouraging results in that there are good responses in TNBC-patients who harbour a $B R C A 1$ mutation, but not in others. This can be explained by the requirement for both genes (BRCA1 and PARP) to be engaged in DNA repair, so if both fail to function any DNA damage will not be repaired and the cell undergoes apoptosis [16]. A phase 2 clinical trial with the PARP-inhibitor iniparib showed promising results, increasing clinical benefit of chemotherapy from $34 \%$ to $56 \%$ and the rate of overall response to chemotherapy from $32 \%$ to $52 \%$, overall survival was improved from 7.7 to 12.3 months [17]. Unfortunately the subsequent phase 3 clinical trial was negative and did not meet the criteria for progression-free survival and overall survival [18]. Angiogenesis inhibitors are being tested in TNBC patients since they show a high level of intra-tumoral vascular endothelial growth factor (VEGF) compared to non-TNBC patients [19]. A meta-analysis of three clinical trials (E2100, AVADO, RIBBON-1), testing a VEGF inhibitor (bevacizumab) in combination with chemotherapy, revealed improved progression-free survival ( 8.1 months versus 5.4 months), a change in relative risk ( $42 \%$ versus $23 \%$ ), but no overall survival benefit [20]. About $45 \%-70 \%$ of TNBC patients show epidermal growth factor receptor (EGFR) over-expression [21]; which has led to clinical trials of EGFR-targeted therapies. The combination of cetuximab (an EGFR inhibitor) and chemotherapy increased the overall response rate from $10 \%$ to $20 \%$, progression-free survival from 1.5 to 3.7 months and overall survival from 9.4 to 12.9 months [22]. Src tyrosine kinase inhibitors have been tested, as the Src tyrosine kinase is often over-expressed in aggressive breast cancers [23]. However, Src inhibitors like dasatinib have almost exclusively been tested in cell lines and not in patients [24]. A phase 1 clinical trial showed a partial response in $31 \%$ of patients and $29 \%$ of patients had stable disease after treatment [25]. The androgen receptor is expressed in most breast cancers, including TNBC (70\%) [26] and its role in TNBC has recently been reviewed [27]. Clinical trials for androgen receptor inhibitors for the targeted treatment of TNBC are still in early stage development. In a phase 2 study, in patients with ER/PR-negative and androgen receptor positive advanced breast cancer, the anti-androgen agent bicalutaminde has shown a 6 month clinical benefit rate of $19 \%$ and the median progression-free survival was 12 weeks [28].

There has been growing interest in DNA damaging agents such as platinum agents (cisplatin and carboplatin) as a treatment option for TNBC. As described above, TNBC is associated with BRCA mutations and a high proliferation rate which increases the sensitivity of this subtype to interstrand cross-linking agents such as platinum agents, when compared to other breast cancer subtypes. A recent systematic review by Petrelli et al. [29] on 28 studies that investigated platinum based neoadjuvant therapy in TNBC patients showed that TNBC patients receiving platinum based neoadjuvant therapy have a significantly increased pathological complete response rate, compared to those not receiving neoadjuvant therapy. Further, they were able to show that TNBC patients have a threefold increased pathological complete response rate compared to non-TNBC subtypes.

\section{Better Classification of TNBC to Find New Treatment Targets and Prognostic Indicators}

Molecular subtypes of breast cancer have been based on gene expression patterns. Breast cancers were first divided into 4 subtypes: ER+/luminal-like, basal-like, HER2-enriched and normal breast-like [30] in 2000. However, this has been further defined in 2007 as six different subtypes with 
luminal-like now further subdivided into luminal A and B, and the additional classification of a claudin low subtype [31]. A report by Prat and Perou in 2011 showed that the majority of TNBCs are from the basal-like subtype (49\%), followed by the claudin-low subtype (30\%), then the HER2-enriched $(9 \%)$, luminal A (5\%), luminal B (6\%), and normal-like (1\%) subtypes [32]. However, with the advent of new technologies such as massively parallel sequencing it is likely that further subtypes will be revealed [33].

The heterogeneity of and difficulty in treating TNBC led Lehmann et al. to define six TNBC subtypes to provide the necessary discrimination for the development of new molecular-based treatment options [34]. The six subtypes, based on gene expression analysis, include two basal-like (BL1 and BL2), an immune-modulatory, a mesenchymal, a mesenchymal stem-like, and a luminal androgen receptor subtype. However, there were still samples that could not be categorized into one of these six subtypes (12\%). Thus, a better classification scheme of these tumours is still required to accurately classify women with TNBC. More recently, a study by Burstein et al. [35] decreased the number of TNBC subtypes to four (luminal androgen receptor, mesenchymal, basal-like immunosuppressed, and basal-like immune-activated). They analysed RNA and DNA profiles from 198 TNBC samples and confirmed their results in seven external publically available datasets. This study also identified subtype specific targets, for the luminal androgen receptor subtype: the androgen receptor, and the cell surface mucin MUC1, for the mesenchymal subtype: growth factor receptors PDGFRA and c-Kit, for the basal-like immunosuppressed subtype: an immunosuppressing molecule VTCN1 and lastly for the basal-like immune-activated subtype: STAT signal transduction molecules and cytokines.

The heterogeneity in gene expression profiles is associated with distinct outcomes in TNBC patients. A recent study by Prat et al. used 1055 TNBC samples from all intrinsic TNBC subtypes. Prat et al. [36] revealed that TNBC patients with high expression of the basal-like or low expression of the luminal A signature were associated with a pathological complete response and improved survival following chemotherapy. Another study performed global proteomic profiling on two independent TNBC cohorts and identified one protein associated with good prognosis (trpRS) while two proteins were poor prognostic markers (DP, TSP1) [37]. Another study by Shen et al. (2014) shows the difficulties in identifying prognostic markers for TNBC. They tested for lymph node status, age, tumour size, histological grade, lymphovascular invasion, P53 status, Ki-67 index, and type of surgery, and found that only lymph node status was marginally significantly associated with poor prognosis. They also identified three miRNAs that were significantly higher expressed in metastatic TNBC compared to the disease-free group [38]. A further issue is that most studies only identify differences between tumours without identifying initial changes from the healthy/normal tissue that lead to cancerous growth and tumour initiation. This is partly due to the fact that the availability of healthy tissue is limited in research. Another approach is the use of normal adjacent tissue, which has been shown to have an expression profile characteristic of DNA repair deficiency [39,40]. Altogether, this evidence unequivocally indicates that a better classification scheme that can be reliably used to subdivide all TNBC samples into their respective groups depending on their prognosis and that is distinct from normal breast tissue is required to provide the appropriate information to tailor treatment options.

There has been an enormous amount of new research in recent years focusing on genetic and epigenetic changes associated with the development and progression of breast cancer. In this review we will focus on some of these changes especially microRNAs, DNA methylation and gene expression changes in TNBC.

\section{Epigenetic Changes in TNBC—New Biomarkers?}

One approach to identify biomarkers for TNBC is the analysis of epigenetic changes. Epigenetics is the study of heritable changes in the phenotype that does not involve any change in DNA sequence. In 1942 Conrad H. Waddington coined the words "epigenesis" and "genetics" to epigenetics to describe the "causal mechanisms" by which "the genes of the genotype bring about phenotypic effects" [41]. Due to the lack of experimental tools and overall knowledge it took over 50 years until 
scientists started to understand the underlying mechanisms of Waddington's observations [42]. To date, multiple discoveries have been made revealing epigenetics can change a phenotype without altering the DNA sequence. These are the classical epigenetic mechanisms like histone modification, chromatin remodelling, and DNA methylation and also the more recently discovered epigenetic changes through small/non-coding RNAs such as miRNAs. These have been extensively reviewed in [43].

There remain many open questions about the mechanisms involved in epigenetic control but it is recognised that epigenetic change can occur due to environmental factors such as stress and cell damage. But there is little known about how genes are activated only when they are required. An increase in the understanding of epigenetic mechanisms and their contribution to disease development has led to a growing interest in the field of epigenetics. For the remainder of this review we will focus on microRNAs and DNA methylation control specifically associated with triple negative breast cancer.

\section{MicroRNAs}

MicroRNAs (miRNAs) are small (18-21 nucleotides) non-coding RNAs, which are capable of altering gene expression post-transcriptionally. In 1993, the lin-4 miRNA was discovered in Caenorhabditis elegans, where it was shown to decrease the levels of Lin-4 protein, by binding to the $3^{\prime}$ UTR region of its respective mRNA sequence [44]. Since that ground-breaking finding, microRNAs have been found to be highly conserved between species, suggesting they play a universal role in the regulation of gene expression. miRNAs regulate multiple biological processes including proliferation, cell death, development, and genomic stability [45]—all essential for tumour development. They not only regulate physiological conditions but also pathological ones, such as those involved in malignancy [46,47]. More than 2500 mature miRNAs have been identified in humans (miRBase v21) [48], but the functionality of most is yet to be discovered. One miRNA can interact with multiple ( $>100)$ target genes and one gene can be controlled by multiple miRNAs [49]. More than $60 \%$ of all protein coding genes have conserved miRNA binding sites in their $3^{\prime}$ UTR region, which affords them the possibility of control by their respective miRNAs [50].

miRNAs offer several advantages for expression analysis compared to mRNA: (1) they are small and therefore more stable; (2) they can be extracted from frozen tissue, formalin-fixed paraffin-embedded tissues as well as blood, with little/no degradation, which makes them ideal for clinical purposes, especially in relation to TNBC diagnosis and treatment.

The biogenesis of miRNAs has been extensively reviewed elsewhere [51] and is not the focus of this review. Briefly, miRNAs are generated endogenously through a series of steps, RNA polymerase II (or sometimes III) transcribes miRNAs in the nucleus as primary transcripts-pri-miRNA ( $\sim 500-3000$ nucleotides). Drosha (RNase) and DGCR8 (gene coding) shorten the pri-miRNA to $\sim 70$ nucleotides and build a stem-loop, which is called precursor miRNA (pre-miRNA). Exportin 5 transfers the pre-miRNA into the cytoplasm, where Dicer (RNase) cuts it into 22-nucleotide RNA duplexes. In most cases, the strand with less paired bases on the $5^{\prime}$ end is the mature miRNA, whereas the other strand is degraded. The mature miRNA builds a complex with the Argonaute 2 protein and the heterodimer of R2D2 \& Dicer-2 proteins to form the RNA-induced silencing complex (RISC) $[45,46,52,53]$. The RISC complex is able to silence the expression of a target gene, by binding to the $3^{\prime}$ UTR of the target gene (mRNA). The binding inhibits the ribosome from translating the gene, which leads to reduced expression of the target gene [53,54].

There are three possible ways that miRNAs can negatively affect the translation of its target mRNA. If the base pairing between mRNA and miRNA is complete, it is most likely that degradation of the mRNA follows due to decreased steric hindrance. Secondly, by incomplete binding, the initiation site for the RNA-Polymerase is blocked leading to decreased mRNA transcription. The third option is that the miRNA-RISC complex translocates to so-called processing bodies (P-bodies), which lack ribosomal components and function as an mRNA storage and can mediate mRNA decay [55]. In contrast, some miRNAs are able to activate translation of their target mRNA when the cell is quiescent 
(not dividing and not preparing to divide), but this is the minority [56]. In these ways, miRNAs are able to knockout (or sometimes overexpress) genes that are important for the control of cellular homeostasis.

\subsection{MicroRNAs in Cancer}

In 2002 it was shown the first time that miRNAs are involved in cancer [57]. Calin et al. [57] discovered that miR-15a and miR-16-1 are located in a region that is frequently lost in leukaemia patients and that both miRNAs are deleted or significantly down-regulated in almost $70 \%$ of all chronic lymphocytic leukaemia patients. Since that initial discovery, cancer-associated miRNAs became classified as either oncogenic microRNAs (oncomiR) or tumour-suppressive microRNAs (tumour suppressor miR). These miRNAs are usually located in cancer-associated gene regions [57]. Whereas oncomiRs are frequently up-regulated in cancer, they target tumour suppressor genes for degradation and promote cancer cell growth; tumour suppressor miRs are usually down-regulated in cancer, they target oncogenes for degradation and have an anti-tumour function [58]. Inhibition of oncomiRs and overexpression of tumour suppressor miRs are therefore promising for targeted therapies in cancer. In almost all stages of the cancer process (cell cycle, apoptosis, invasion, angiogenesis), dysregulated miRNA expression has been found, when compared to normal tissue [59]. Altered miRNA expression profiles have been found in every type of human cancer (that has been studied so far) including colon cancer, brain tumours, lung cancer and breast cancer, where they mainly work as tumour suppressor miRs or oncomiRs $[60,61]$. These findings suggest that miRNAs may be possible biomarkers for early cancer detection $[49,62,63]$.

\section{2. miRNAs Involved in Triple Negative Breast Cancer}

Over the last 10 years there have been multiple studies identifying miRNA changes associated with TNBC. Here we review and summarise the latest miRNA profiling (Table 1), functional (Table 2), and prognostic (Table 3) findings that have been implicated in the pathology of TNBC. We have also included studies in other breast cancer subtypes, where they analysed miRNAs targeting one of the three receptors (ER, PR, HER2, i.e., miRs targeting these receptors may be responsible for the lack of receptor expression in TNBC) or those miRs associated with metastasis in other breast cancer subtypes, since these studies may allow us to gain further insight into miRNAs that may be involved in TNBC. While the majority of studies have compared TNBC against other breast cancer subtypes in an effort to determine miRNA signatures that can define this subtype, there have only been two studies which have focused on miRNA expression changes during tumour progression to identify biomarkers associated with the development of lymph node metastasis in TNBC samples. These studies performed miRNA profiling purely on TNBC samples (including our own [64]), identifying altered miRNA expression between tumour, matched normal and matched lymph node metastasis samples $[64,65]$ and this represents an important area of investigation given the increased likelihood of TNBC to metastasize. A number of miRNAs have been identified and validated that target key genes involved in critical cellular functions. As an example, the miR-200 family targets ZEB1/ZEB2, Suz 12, EphA2, MSN, FN1, TrkB, XIAP, all of which are important for cell proliferation, invasion, and migration [66-69]. Multiple studies have revealed various miRNAs that specifically target the three missing receptors ER, PR, and HER2 as well as the breast cancer susceptibility gene BRCA1 in TNBC development (see Table 1). The most recent study of prognostic miRNAs by Liu et al. (2015) identified a signature of four miRNAs that appeared to be associated with a good prognosis in TNBC (miR-374b-5p $\uparrow$, miR-218-5p $\uparrow$, miR-126-3p $\uparrow$, miR-27b-3p $\downarrow$ ). The following Tables summarise a broad overview of all three study types (profiling, prognostic and functional studies in cell lines) and their findings contributing to the current knowledge regarding miRNAs in TNBC. Overall, there is considerable inconsistency in the results of these studies and the effects of these miRNAs on various aspects of TNBC biology. This clearly suggests that there remains a need for better validation and reliability in the experimental conditions and subsequent analysis to define specific miRNAs as biomarkers of disease. 
Table 1. MicroRNAs that have been associated with TNBC, the three receptors (ER, PR, HER2), and/or metastasis in profiling studies. MicroRNAs written in bold face have been analyzed in multiple studies. $\downarrow$ indicates down-regulation, $\uparrow$ indicates up-regulation.

\begin{tabular}{|c|c|c|c|}
\hline miRNA & Result & Technology & References \\
\hline miR-342, miR-299, miR-217, miR-190, miR-135b, miR-218 & Associated with ER status & \multirow{3}{*}{$\begin{array}{l}\text { Expression profiling of } 453 \text { miRNAs, } 29 \text { breast cancer cases } \\
\text { (mixed receptor status) }\end{array}$} & \multirow{3}{*}{ [70] } \\
\hline miR-520g, miR-377, miR-527-518a, miR-520f-520c & Associated with PR status & & \\
\hline miR-520d, miR-181c, miR-302c, miR-376b, miR-30e & Associated with HER2/neu status & & \\
\hline miR-532-5p, miR-500, miR362-5p, miR-502-3p & $\begin{array}{l}\text { Located at Xp11.23 and present in TNBC, } \\
\text { compared to other subtypes }\end{array}$ & \multirow{2}{*}{$\begin{array}{l}\text { miRCURY LNA arrays ( } 2090 \text { miRNAs analysed) } 103 \text { lymph } \\
\text { node negative cases (mixed breast cancer subtypes) }\end{array}$} & \multirow[t]{2}{*}{ [71] } \\
\hline Signature of 41 miRNAs & Associated with TNBC subtype & & \\
\hline Signature of 116 deregulated miRNAs & First study purely focused on miRNAs in TNBC & \multirow{4}{*}{$\begin{array}{l}\text { nanoString nCounter profiling (664 miRNAs analysed) } \\
173 \text { TNBC samples }\end{array}$} & \multirow{4}{*}{ [65] } \\
\hline miR-106b, miR-17/92 cluster, miR-200 family, miR-21, miR-155 & Most up-regulated & & \\
\hline let-7b, let-7c, miR-126, miR-145, miR-205 & Most down-regulated & & \\
\hline miR-424, miR-125a-5p, miR-627, miR-579, let-7g, miR-101 & Associated with metastasis & & \\
\hline miR-130a & $\begin{array}{l}\text { Second study purely on TNBC. Novel miRNAs, } \\
\text { up-regulated in TNBC }\end{array}$ & \multirow{3}{*}{$\begin{array}{l}\text { Agilent miRNA microarrays ( } 904 \text { miRNAs analysed) } \\
31 \text { tumours, } 13 \text { lymph node metastasis, } 23 \text { normal } \\
\text { adjacent tissues }\end{array}$} & \multirow{3}{*}[64,65]{} \\
\hline miR-1280, miR-590-5p, miR-1308, miR-17* & Novel miRNAs, down-regulated in TNBC & & \\
\hline 27 miRNA signature & $\begin{array}{l}\text { Associated with lymph node metastasis, } \\
\text { majority (25) are down-regulated }\end{array}$ & & \\
\hline miR-145, miR-205 & $\begin{array}{l}\downarrow \text { in TNBC (preferentially expressed in normal } \\
\text { myoepithelial cells) }\end{array}$ & Tissue microarrays 100 TNBC samples & [72] \\
\hline miR-17-92 cluster, miR-106b-25 cluster & $\begin{array}{l}\text { Associated with oncogenic processes EMT, } \\
\text { PI3K/Akt/mTOR, MYC, PTEN }\end{array}$ & $\begin{array}{l}\text { miRNA and gene expression arrays, prediction software, } \\
\text { data integration (miRNA arrays, (based on Sanger miRBase } \\
\text { release 12.0, containing probes for } 866 \text { miRNAs) ( } 29 \text { mixed } \\
\text { breast cancer subtypes)) }\end{array}$ & [73] \\
\hline miR-342, miR-299, miR-217, miR-190, miR-135b, miR-218 & Markers for ER status & \multirow{3}{*}{$\begin{array}{l}\text { miRNA microarray, network algorithms, qPCR } \\
\text { (453 miRNAs analysed) (mixed breast cancer subtypes) }\end{array}$} & \multirow{3}{*}{ [70] } \\
\hline miR-520g, miR-377, miR-527-518a, miR-520f-520c & Markers for PR status & & \\
\hline miR-520d, miR-181c, miR-302c, miR-376b, miR-30e & Markers for HER2 & & \\
\hline miR-93 & Associated with ER and PR status & $\begin{array}{l}\text { miRNA profiling, qPCR ( } 3 \text { miRNAs analysed) (TaqMan } \\
\text { MicroRNA Assays) ( } 37 \text { mixed breast cancer subtypes) }\end{array}$ & [74] \\
\hline miR-200c, miR-205 & $\begin{array}{l}\text { Lower levels are associated with lymph node } \\
\text { metastasis in TNBC }\end{array}$ & $\begin{array}{l}\text { qPCR from tumour samples (16 miRNAs analysed) } \\
\text { ( } 32 \text { TNBC samples) }\end{array}$ & [75] \\
\hline miR-373, miR-10b & $\uparrow$ regulated in cases with lymph node metastasis & $\begin{array}{l}\text { qPCR from tumour samples ( } 2 \text { miRNAs analysed) (TaqMan } \\
\text { MicroRNA Assays) ( } 60 \text { mixed breast } \\
\text { cancer subtypes) }\end{array}$ & [76] \\
\hline
\end{tabular}


Table 2. MicroRNAs that have been associated with TNBC, the three receptors (ER, PR, HER2), and/or metastasis in functional studies. MicroRNAs written in bold face have been analyzed in multiple studies. $\downarrow$ indicates down-regulation, $\uparrow$ indicates up-regulation.

\begin{tabular}{|c|c|c|c|}
\hline miRNA & Result & Functional Evidence & References \\
\hline $\mathrm{miR}-200 \mathrm{a} / \mathrm{b}$ & $\begin{array}{l}\text { Tumour suppressor-miR/targets ZEB1/ZEB2, Suz 12, EphA2/plays role during differentiation in } \\
\text { mammary epithelial cells }\end{array}$ & Cell culture experiment (differentiation) and qPCR (non-TNBC cell line HC11 mouse mammary) & [66] \\
\hline $\mathrm{miR}-200 \mathrm{c}$ & Tumour suppressor-miR/targets ZEB1/ZEB2, MSN, FN1, TrkB/inhibits EMT and migration & $\begin{array}{l}\text { Dual luciferase reporter assays, wound healing assays, cell-death ELISAs, and viability assays } \\
\text { (non-TNBC cell lines: Hec50, AN3CA, MCF7; TNBC cell lines: MDA-MB-231, BT549) }\end{array}$ & {$[67,68]$} \\
\hline miR-205 & Tumour suppressor-miR/targets E2F1, LAMC1/supresses proliferation, cell cycle and tumour growth & $\begin{array}{l}\text { Transfections, qPCR, colony formation assay, proliferation assay, cell cycle analysis, apoptosis } \\
\text { assay, viability assay, senescence assay, western blot, chip assay (non-TNBC cell lines: HEK-293, } \\
\text { MCF7, SAOS-2; TNBC cell lines: MDA-MB-231, BT549) }\end{array}$ & [77] \\
\hline $\operatorname{miR}-203$ & Tumour suppressor-miR/targets BIRC5, LASP1/inhibits proliferation and migration & $\begin{array}{l}\text { qPCR, transfection, proliferation and migration assays, luciferase reporter assay (non-TNBC cell } \\
\text { lines: MCF-10A (normal); TNBC cell lines: MDA-MB-231, MDA-MB-468) }\end{array}$ & [78] \\
\hline miR-31 & $\begin{array}{l}\text { Tumour suppressor-miR/targets WAVE3, RhoA, Radexin, } P R K C E / \text { suppresses metastatic potential, } \\
\text { induction of apoptosis, increase of chemo-sensitivity }\end{array}$ & $\begin{array}{l}\text { Transfection, qPCR, dual luciferase reporter assays, invasion assay, western blot, apoptosis assay, } \\
\text { viability assay (non-TNBC cell lines: T-47D, MCF7, MCF-10A; TNBC cell lines: MDA-MB-231, } \\
\text { MDA-MB-435, BT549) }\end{array}$ & {$[79,80]$} \\
\hline miR-34a & Tumour suppressor-miR/targets $A X L /$ inhibits migration & $\begin{array}{l}\text { Target prediction, qPCR, dual luciferase reporter assays, DNA capture assay, western blot, } \\
\text { proliferation and migration assays, cell cycle analysis (non-TNBC cell lines: MCF7, SK-BR-3, T47D; } \\
\text { TNBC cell lines: MDA-MB-231, BT549, Hs578T) }\end{array}$ & [81] \\
\hline $\mathrm{miR}-181 \mathrm{a} / \mathrm{b}$ & Onco-miR/targets Bim, $A T M /$ inhibits anoikisis, impairment of DNA double strand break repairs & $\begin{array}{l}\text { Transfection, miRNA microarray, 3D cell culture, proliferation, migration and invasion assays, } \\
\text { qPCR, dual luciferase reporter assays, tumour growth and metastasis assay, cell cycle analysis } \\
\text { (non-TNBC cell lines: NMMUMG, MCFA, HEK 293GP, SUM159PT, OVCAR,HT29, PANC1, SK-Br-3; } \\
\text { TNBC cell lines: MDA-MB-231, MDA-MB-468) }\end{array}$ & {$[82,83]$} \\
\hline $\operatorname{miR}-146$ & Onco-miR/targets $B R C A 1 /$ effects $B R C A 1$-mediated proliferation and homologous recombination & $\begin{array}{l}\text { Target prediction, transfections, qPCR, northern blot, western blot, dual luciferase reporter assays, } \\
\text { proliferation assay (TNBC cell lines: MDA-MB-436, MDA-MB-157) }\end{array}$ & [84] \\
\hline miR-182 & Onco-miR/targets $P F N 1$ increases proliferation and invasion, decreases apoptosis & $\begin{array}{l}\text { Transfections, proliferation assay (MTT and flow cytometry), apoptosis assay, invasion assay, dual } \\
\text { luciferase reporter assays, western blot (TNBC cell line MDA-MB-231) }\end{array}$ & [85] \\
\hline miR-200 family & Inhibits cancer cell migration, invasion, if low $\rightarrow$ poor response to chemotherapy and radiotherapy & $\begin{array}{l}\text { qPCR, dual luciferase reporter assays, immunoblot and immunofluorescence assay, migration } \\
\text { assay, ChIP assay, viability assay, clonogenic assay, western blot (non-TNBC cell lines: NMuMG, } \\
\text { HeLa, MCF7; TNBC cell lines: MDA-MB-231) }\end{array}$ & [86-89] \\
\hline Let-7 family & Tumour suppressor-miRs $\downarrow$ in TNBC/target onco-genes $R A S, M Y C, H M G A 2$ & c. elegans, mice, cell culture, transfections & {$[90,91]$} \\
\hline $\begin{array}{l}\text { miR-15a,b, miR-16, } \\
\text { miR-128 }\end{array}$ & $\begin{array}{l}\text { Target Smurf2 (tumour suppressive ubiquitin) which down-regulates retinoblastoma } \\
\text { (tumour suppressor) in TNBC }\end{array}$ & $\begin{array}{l}\text { Immunohistochemistry, qPCR, transfection (non-TNBC cell lines: MCF-10A (normal breast), } \\
\text { MCF9, T47D, SK-Br-3, BT747; TNBC cell lines: MDA-MB-231, MDA-MB-468, BT549, } \\
\text { MDA-MB-436, DU4475) }\end{array}$ & [92] \\
\hline miR-200c & Targets X-linked inhibitor of apoptosis (XIAP), what then suppresses proliferation in TNBC & $\begin{array}{l}\text { Transfections, qPCR, colony formation assay, proliferation assay, flow cytometry, western blot, } \\
\text { luciferase reporter assays, mice tumour model (non-TNBC cell lines: MCF-10A (normal breast); } \\
\text { TNBC cell lines: MDA-MB-231) }\end{array}$ & [69] \\
\hline miR-221 & $\begin{array}{l}\text { Onco-miR/promotes tumourigenesis in TNBC/if knocked-down cell cycle progression and induction of } \\
\text { apoptosis is inhibited }\end{array}$ & $\begin{array}{l}\text { Transfections, qPCR, immunoblotting, proliferation, migration, invasion, and apoptosis assays, } \\
\text { cell cycle analysis, mice tumour analysis (non-TNBC cell lines: SKBR3, MDA-MB-361, T47D, } \\
\text { ZR75-1, MCF-7; TNBC cell lines: MDA-MB-231, Hs-578T, BT-20, and MDA-MB-468) }\end{array}$ & [93] \\
\hline miR-31 & $\begin{array}{l}\text { Antimetastatic-miR/when } \downarrow \text { regulated in TNBC more metastases/down-regulated due to } \\
\text { promoter methylation }\end{array}$ & $\begin{array}{l}\text { qPCR, bisulfite-modified DNA for methylation analysis, DNA sequencing, methylation specific } \\
\text { PCR (non--NBC cell lines: MCF-10A (normal breast), MCF7, SKBR3, T47D; TNBC cell lines: } \\
\text { MDA-MB-231, BT549, MDA-MB-4355) }\end{array}$ & [94] \\
\hline miR-200b & Targets protein kinase $C \alpha$ and suppresses metastasis in TNBC & $\begin{array}{l}\text { qPCR, transfection, luciferase reporter assays, migration assay, mouse xenograft model, } \\
\text { immunohistochemistry, western blot, pulldown assay, MTT assay, colony formation assay } \\
\text { (non--TNBC cell lines: MCF-7, T-47D, BT-474, SKBR-3; TNBC cell lines: MDA-MB-468, BT-20, } \\
\text { Hs578T and BT-549, MDA-MB-453) }\end{array}$ & [95] \\
\hline $\begin{array}{l}\text { miR-22, miR-27a, miR-206, } \\
\text { miR-221/222, miR-302c }\end{array}$ & Associated with ER signalling and endocrine resistance & $\begin{array}{l}\text { Immunohistochemistry, qPCR, transfections, clonogenicity assay, microarray, western blot, } \\
\text { viability assay, luciferase reporter assays (non-TNBC cell lines: MCF-7, BT-474, T47D, SK-BR-3; } \\
\text { TNBC cell lines: MDA-MB-231) }\end{array}$ & [96-99] \\
\hline $\begin{array}{l}\text { miR-125b, miR-134, } \\
\text { miR-193a-5p, miR-199b-5p, } \\
\text { miR-331-3p, miR-342-5p, } \\
\text { miR-744* }\end{array}$ & Associated with HER2 signalling and trastuzumab resistance & $\begin{array}{l}\text { luciferase reporter assays, northern and western blot, proliferation, migration and invasion assays, } \\
\text { microarray, qPCR, transfections (non-TNBC cell lines: MCF-10A (normal breast), SK-BR-3, KPL-4, } \\
\text { JIMT-1, MCF-7, BT-474; TNBC cell lines: MDA-MB-231) }\end{array}$ & [100-102] \\
\hline $\mathrm{miR}-23 \mathrm{~b} / 27 \mathrm{~b} / 24$ cluster & Promotes metastasis by targeting prosaposin (=metastasis-suppressive gene) & $\begin{array}{l}\text { Microarrays, qPCR, migration assay, tumour xenografts, luciferase reporter assays, western blot } \\
\text { (non-TNBC cell lines: HeLa; TNBC cell lines: MDA-MB-231, 67NR, 168FARN, 4TO7, 66cl4, 4T1) }\end{array}$ & [103] \\
\hline
\end{tabular}


Table 3. MicroRNAs that have been associated with TNBC, the three receptors (ER, PR, HER2), and/or metastasis in prognostic studies. MicroRNAs written in bold face have been analyzed in multiple studies.

\begin{tabular}{|c|c|c|c|}
\hline miRNA & Result & Predictive/Prognostic & References \\
\hline miR-200 family & $\begin{array}{l}\text { Inhibits cancer cell migration, invasion, if low } \rightarrow \text { poor response to chemotherapy and } \\
\text { radiotherapy (non-TNBC based studies \& TNBC study [88]) }\end{array}$ & predictive & [86-89] \\
\hline miR-21 & Onco-miR/associated with poor prognosis/ $/$ expressed in TNBC & prognostic & [104] \\
\hline miR-155 & $\begin{array}{l}\text { Onco-miR/associated with poor prognosis, angiogenesis, tumour growth, } \\
\text { metastases/controlled epigenetically by } B R C A 1 \uparrow \text { expressed in TNBC }\end{array}$ & prognostic & [105] \\
\hline miR-16, miR-155, miR-374 & Prognostic miR/if $\uparrow$ associated with better prognosis (overall survival) (TNBC based study) & \multirow{4}{*}{ prognostic } & \multirow{4}{*}{ [65] } \\
\hline miR-125b & Prognostic miR/if $\downarrow$ associated with poor prognosis (overall survival) (TNBC based study) & & \\
\hline miR-125b, miR-655, miR-421 & Risk associated miRs/associated with distant disease free survival (TNBC based study) & & \\
\hline miR-16, miR-374a,b, miR-497 & Protective miRs/associated with distant disease free survival (TNBC based study) & & \\
\hline miR-210 & $\begin{array}{l}\uparrow \text { regulated in TNBC compared to ER+ breast cancers/associated with early relapse/low } \\
\text { levels are associated with better disease free survival in TNBC }\end{array}$ & prognostic & {$[104,106,107]$} \\
\hline miR-34b & $\begin{array}{l}\text { Associated with p53-pathway/negative correlation with disease free survival and overall } \\
\text { survival (TNBC based study) }\end{array}$ & prognostic & {$[108,109]$} \\
\hline miR-376b, miR-409-5p, miR-410miR-193a-3p & Associated with worse breast cancer specific survival (TNBC based study) & \multirow{4}{*}{ prognostic } & \multirow{4}{*}{ [73] } \\
\hline miR-16-2* $\uparrow$, miR-381 $\downarrow$, miR-409-5p $\downarrow$, miR-766 $\uparrow$ & Associated with better distant metastasis free survival (TNBC based study) & & \\
\hline $\begin{array}{l}\text { miR-766, miR-33b*, miR-550, miR-1539, miR-548d-5p, miR-16-2*, } \\
\text { miR-563, miR-155* }\end{array}$ & Positively correlation with prognosis (TNBC based study) & & \\
\hline miR-193a-3p, miR-432, miR-376b, miR-381, miR-409-5p, miR-410 & Negatively correlated with prognosis (TNBC based study) & & \\
\hline miR-342, miR-150 & miRNAs for good prognosis (TNBC based study) & \multirow{2}{*}{ prognostic } & \multirow{2}{*}{ [110] } \\
\hline miR-27b, miR-210, miR-144 & miRNAs for poor prognosis (TNBC based study) & & \\
\hline miR-21 & $\begin{array}{l}\text { Onco-miR } / \uparrow \text { regulated in TNBC/associated with poor prognosis, shorter recurrence-free } \\
\text { survival and increased proliferation }\end{array}$ & prognostic & {$[111,112]$} \\
\hline miR-155 & $\begin{array}{l}\text { Onco-miR } \uparrow \text { regulated in TNBC/targets tumour suppressor } V H L \text { and promotes } \\
\text { angiogenesis/associated with poor prognosis }\end{array}$ & prognostic & [113] \\
\hline miR-200b-3p $\uparrow, m i R-190 a \uparrow, m i R-512-5 p \downarrow$ & In this combination associated with better response to chemotherapy (TNBC based study) & predictive & [114] \\
\hline miR-155-5p, miR-21-3p, miR-181a-5p, miR-181b-5p, miR-183-5p & $\uparrow$ regulated in TNBC/associated with chemoresistance & predictive & [115] \\
\hline $\begin{array}{l}\text { miR-10b-5p, miR-451a, miR-125b-5p, miR-31-5p, miR-195-5p, } \\
\text { miR-130a-3p }\end{array}$ & $\downarrow$ regulated in TNBC/associated with chemoresistance & predictive & [115] \\
\hline miR-155, miR-30e, miR-27a, miR-493 & Biomarkers dividing TNBC into low and high level risk groups & prognostic & [116] \\
\hline miR-10b & $\begin{array}{l}\uparrow \text { in TNBC/promotes tumour invasion and metastasis/shorter progression free and overall } \\
\text { survival/by targeting HoxD10 (which depresses expression of prometastatic gene RhoC) }\end{array}$ & prognostic & {$[76,117-119]$} \\
\hline miR-374b-5p, miR-218-5p, miR-126-3p & When $\uparrow$ in TNBC associated with good prognosis & prognostic & \multirow{2}{*}{ [120] } \\
\hline miR-27b-3p & When $\downarrow$ in TNBC associated with good prognosis & prognostic & \\
\hline
\end{tabular}




\subsection{MicroRNAs and Metastasis/Epithelial to Mesenchymal Transition (EMT)}

As discussed previously, TNBCs have an increased propensity to metastasize and the majority of deaths from this disease are a result of distant disease. Epithelial-mesenchymal-transition (EMT) has become the focus of research into the metastatic process. EMT describes a process by which epithelial cells lose their adhesive qualities resulting in increased mobility. The process of EMT was first described as a feature of embryogenesis [121]. There are three types of EMT. Type one describes the process during implantation, embryogenesis and organ development. Type two is involved in wound healing, to generate fibroblasts after tissue injuries. The third type of EMT describes the relationship between EMT and cancer progression [122].

EMT induction involves multiple genes/pathways, for example the genes Src [123], Ras [124], Ets [125], integrins [126], Wnt/ $\beta$-catenin [127,128], Notch [129] and others [122] have been associated with this process. A summary of these pathways is shown in Figure 1 and has been graphically illustrated in a review by Kalluri and Weinberg in [122]. Briefly, EMT can be initiated by growth factors, tumour-stromal cell interaction, or hypoxia. These stimuli create feedback loops with transcription factors, which for the most part, control E-cadherin (a key molecule in EMT). All of these pathways involve multiple genes, all of which could be affected by epigenetic change, such as miRNA expression changes, thereby altering critical pathways involved in this process. A summary of the key miRNAs and their regulation of EMT-related target genes in breast cancer development is shown in Table 4.

There are multiple reports revealing how EMT is affected by various miRNAs [130-136]. All of them demonstrate the inter-connectivity between miRNAs, EMT and cancer progression. In particular, the miR-200 family has roles in proliferation, migration and invasion $[130,132,135,136]$ and has been well-studied in breast cancer research. Basal-like breast tumours are known to have more mesenchymal and EMT features than other subtypes supporting their more aggressive nature [137]. Basal like breast tumours have lower levels of the miR-200 family than luminal or HER2 over-expressing subtypes [138], this also causes higher levels of their target genes (SNAI1/2, and ZEB2). Of the miR-200 family, miR-200c shows the strongest association with the histopathology and disease course, this miRNA is also almost non-existent in TNBC [65,139]. Various studies have also shown that the miR-200 family has dual functions in breast cancer progression [140,141]. These studies reveal in primary breast tumours that miR-200 levels are low, which would lead to increased ZEB1/2 expression and E-cadherin down-regulation [142] and are associated with EMT initiation and subsequent invasion into the blood stream. At the secondary site, miR-200 levels rise and initiate mesenchymal-epithelial transition (MET) culminating in metastatic colonisation.

In TNBC the miR-200 family has also been shown to sensitise cell lines to cell death and to inhibit metastatic growth through inhibition of protein kinase (PKC $\alpha)[95,143]$. Other members of the miRNA-200 family, miR-221/222 have the opposite effect compared to miR-200c, where low miR-221/222 expression improves the differentiation status [135]. miR-130b works in a similar fashion, if it's expression is high, the level of EMT is low [133]. However, there are many more miRNAs that play a role in metastasis that have yet to be fully characterised.

An overview of miRNAs that are known to be involved in metastatic spread and EMT as well as their targets and the target gene expression is provided in Table 4 . This table does not contain all genes and microRNAs known to be involved in metastatic spread and EMT but it does show that this is a complex process with multiple influencing factors.

More recently there has been some controversy regarding the dependency of metastasis on EMT. There are an increasing amount of studies that have identified mechanisms by which cancer cells migrate and metastasise that are EMT-independent [144-147]. During EMT-independent metastasis, neoangiodenic vessels infiltrate the tumour and build a connection to capillary endothelia of distant organs, where metastatic growth occurs [144]. These EMT-independent mechanisms are not well understood and are not the focus of this review. Nevertheless, a number of genes are involved in both processes, including SNAIL, TWIST, ZEB1/2 [144-147]. 


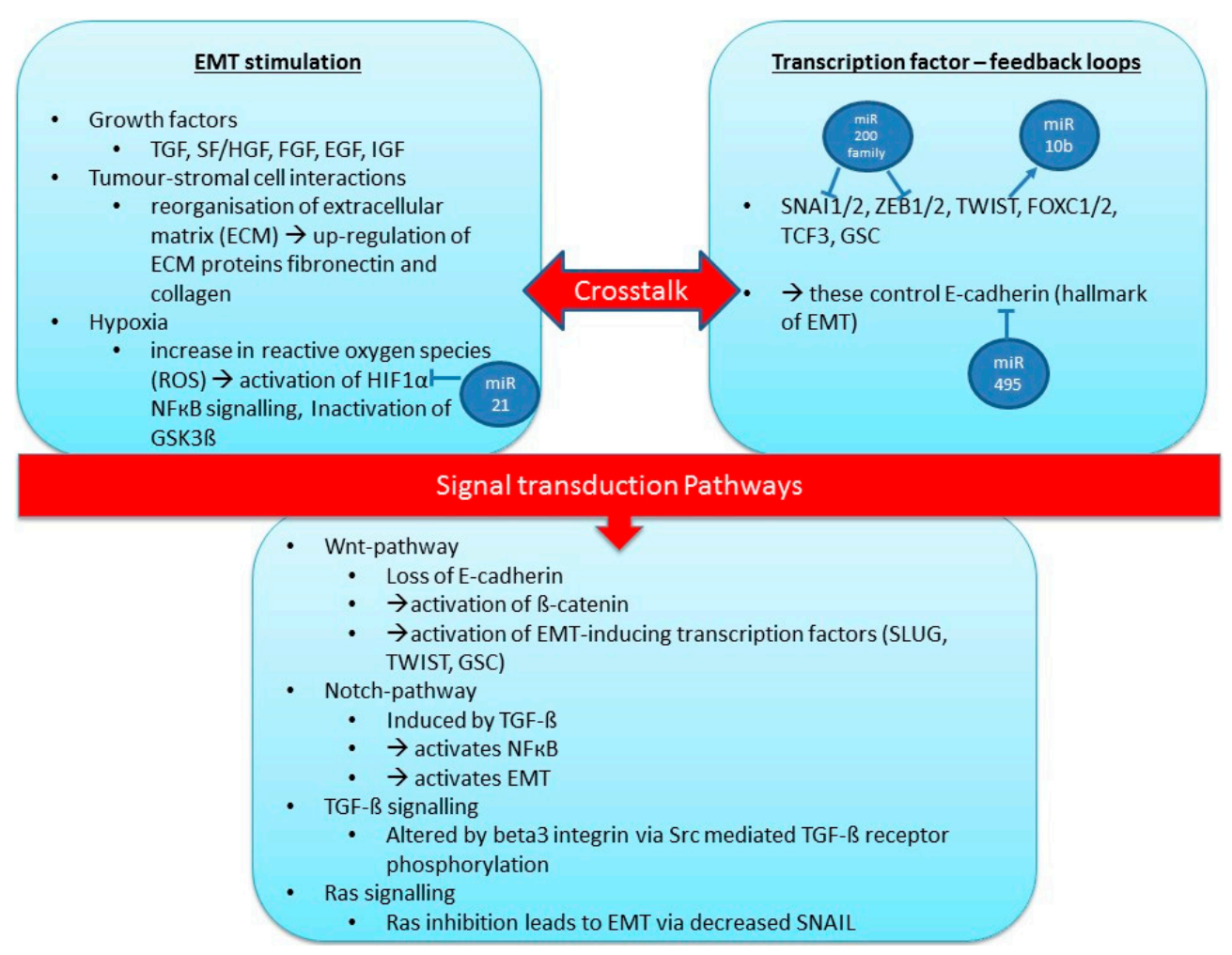

Figure 1. Overview of the process of epithelial-mesenchymal transition (EMT).

Table 4. Overview of microRNAs that are known to be involved in metastatic spread and epithelial-mesenchymal transition (EMT) in breast cancer.

\begin{tabular}{|c|c|c|c|}
\hline EMT-Regulation & miRNA & Comments & References \\
\hline \multirow{8}{*}{ Pro-EMT } & $\operatorname{miR}-21$ & $\begin{array}{l}\text { Associated with invasive and metastatic breast cancer; regulates EMT } \\
\text { and HIF-1a }\end{array}$ & [148-150] \\
\hline & miR-29 & $\begin{array}{l}\text { Activates EMT by down-regulating peroxidasin homologue } \\
\text { (cell adhesion molecule); down-regulation of DNA-methylation of } \\
\text { tumour-suppressor genes; increasing chemosensitivity; targets EMT } \\
\text { regulator } N-m y c\end{array}$ & {$[151,152]$} \\
\hline & $\mathrm{miR}-10 \mathrm{~b}$ & $\begin{array}{l}\text { Targets Tiam1-mediated Rac activation, which controls cell-cell } \\
\text { adhesion and EMT through E-cadherin, leads to increased cell invasion } \\
\text { and migration; Is activated by transcription factor TWIST (binds to } \\
\text { promoter of miR-10b); expression increases during TGF- } \beta \text { induced EMT }\end{array}$ & $\begin{array}{l}{[118,153,} \\
154]\end{array}$ \\
\hline & $\operatorname{miR}-9$ & $\begin{array}{l}\text { Is up-regulated in breast cancer, represses cadherin-1, which regulates } \\
\text { cell adhesion and proliferation }\end{array}$ & {$[155,156]$} \\
\hline & miR-206 & $\begin{array}{l}\text { Suppresses proliferation, targets } E R, S R C-1, S R C-2, G A T A-3 \\
\text { (all estrogen signalling molecules) }\end{array}$ & [157-159] \\
\hline & $\mathrm{miR}-221 / 222$ & Increases proliferation in ER positive cell lines, targets $E R, p 27, p 57$ & {$[97,160,161]$} \\
\hline & miR-495 & Targets E-cadherin, JAM- $A$, and $R E D D 1$ & {$[162,163]$} \\
\hline & miR-181 & Targets PHLAD1 and ATM, associated with reduced survival in TNBC & {$[83,164]$} \\
\hline $\begin{array}{l}\text { Pro-EMT (sometimes } \\
\text { anti-EMT) }\end{array}$ & $\begin{array}{l}\text { miR-17/92 } \\
\text { cluster }\end{array}$ & $\begin{array}{l}\text { Can act as tumour suppressor and oncogene, depending on } \\
\text { microenvironment, mostly pro-metastatic, targets ER and SRC-3 }\end{array}$ & {$[165,166]$} \\
\hline \multirow{4}{*}{ Anti-EMT } & miR-130a & Targets ER, $c-M E T$ (onco-gene), down-regulates miR-221/222 & [167] \\
\hline & $\mathrm{miR}-145$ & $\begin{array}{l}\text { Acts as tumour suppressor, targets ER and MUC-1 } \\
\text { (supports cell invasion) }\end{array}$ & [168-170] \\
\hline & miR-7 & Targets SETDB1 $\rightarrow$ reduction of STAT1, Myc, Twist, and miR-9 & [171] \\
\hline & miR-375 & Targets $S H O X 2$ and IGFR, which leads to suppression of EMT & [172] \\
\hline
\end{tabular}

\subsection{Circulating miRNAs in Breast Cancer}

There is an urgent need for less invasive diagnostic and prognostic biomarkers for breast cancer and in particular for TNBC. The majority of biomarkers to date have been developed from tumours comparing gene/miRNA expression against healthy control samples [65], or different tumour 
subtypes $[30,173]$. More recently circulating miRNAs have become a focus for the development of less invasive biomarkers. Circulating miRNAs can be cell-free single miRNAs, transported in exosomes or other microvesicles and are present in blood, plasma, serum, urine or other body fluids [174]. Recently, there has been an increase in studies focusing on circulating miRNAs in breast cancer, which have been summarised in Table 5 . miR-155 has been the most widely studied circulating miRNA in breast cancer. It is upregulated in the serum of breast cancer patients compared to healthy controls [175-177]. miR-155 expression has been associated with ER/PR/HER2 expression [177]. The expression levels of miR-155 can also discriminate between primary breast cancer and metastatic breast cancer, as the expression decreases significantly in metastatic breast cancers compared to primary cancer and healthy tissue [178]. As a result of these findings, it has been classed as a stable biomarker for breast cancer, confirmed through a meta-analysis of circulating miRNAs in breast cancer [179]. Further to this, it has been found to be down-regulated in breast cancer patients after surgical tumour removal [176]. Very recently TRF-1 has been identified as a target gene of miR-155 [180]. TRF-1 has a sheltering function for chromosome telomeres, which has decreased expression as a result of high miR-155 expression leading to a decrease in genomic stability, metastasis-free survival and relapse-free survival in ER-positive breast cancer patients. Inhibition of miR-155 results in an improvement of telomere function and an increase in genomic stability [180]. Circulating miR-155 is now considered a key regulator in breast cancer development and progression. Nevertheless, there are many other circulating miRNAs with important functions in breast cancer, which have been summarised in Table 5. Similar to other miRNA studies, there is a lack of consistency between studies. A stricter definition of tumour suppressor and oncogenic miRs is required so that significant miRNAs in body fluids and tissue samples can be made to fully appreciate the biological role these nucleic acids have in tumour development. These findings must be replicated in different cohorts before we can call these miRNAs biomarkers. Nevertheless, the majority of these miRNAs have also been identified in tumour samples, which supports their relevance in the involvement in the tumour development and progression (Tables 1-3).

Table 5. Overview of circulating microRNAs identified in breast cancer patients. $\downarrow$ indicates down-regulation, $\uparrow$ indicates up-regulation.

\begin{tabular}{|c|c|c|}
\hline MicroRNA & Study Findings & References \\
\hline $\begin{array}{l}\text { miR-34a, miR-93, miR-373, miR-21, miR-155, } \\
\text { miR-155, miR-181b, miR-24, miR-19a, } \\
\text { miR-21, miR-106, miR-155, miR-29a, miR-21, } \\
\text { miR-20a, miR-21 }\end{array}$ & $\begin{array}{l}\text { Are up-regulated in breast cancer compared to } \\
\text { healthy controls }\end{array}$ & {$[175-179,181-183]$} \\
\hline $\begin{array}{l}\text { miR-299-5p, miR-411, miR-126, miR-199a, } \\
\text { miR-335, miR-181a, miR-1304 }\end{array}$ & $\begin{array}{l}\text { Are down-regulated in breast cancer compared to } \\
\text { healthy controls }\end{array}$ & {$[177,184,185]$} \\
\hline $\begin{array}{c}\text { miR-17, miR-155 ( } \uparrow \text { in primary), miR-10b, } \\
\text { miR-210, miR-214, miR-18b, miR-103, } \\
\text { miR-107, miR-652, miR-101, miR-372, } \\
\text { miR-373 }\end{array}$ & $\begin{array}{l}\text { Discriminating primary tumour from metastatic } \\
\text { tumour }\end{array}$ & {$[178,182,186-189]$} \\
\hline $\begin{array}{l}\text { miR-373, miR-17, miR-34a, miR-21, miR-126, } \\
\text { miR-155, miR-199a, miR-335 }\end{array}$ & Associated with ER/PR/HER2 status & {$[177,178]$} \\
\hline miR-210, miR-214, miR-10b, miR-373 & $\begin{array}{l}\text { Associated with lymph node metastasis; miR-214 } \\
\text { targets PTEN (tumour suppressor) }\end{array}$ & {$[76,182,187]$} \\
\hline $\begin{array}{l}\text { miR-200b, miR-18b, miR-103, miR-107, } \\
\text { miR-652, miR-155 }\end{array}$ & Associated with survival & {$[180,188,190]$} \\
\hline $\begin{array}{c}\text { miR-210 } \downarrow \text { (surgery), miR-214 } \downarrow \text { (surgery), } \\
\text { miR-155, miR-181b, miR-24 } \downarrow \text { (surgery), } \\
\text { miR-19a } \downarrow \text { (therapy) }\end{array}$ & $\begin{array}{l}\text { Levels of miRNA-expression change after } \\
\text { surgery/therapy }\end{array}$ & {$[176,182,187]$} \\
\hline $\begin{array}{l}\text { miR-141, miR-200a,b,c, miR-203, miR-210, } \\
\text { miR-375, miR-810 } \uparrow, \text { miR-768-3p } \downarrow\end{array}$ & $\begin{array}{l}\text { Altered in patients with circulating tumour cells } \\
\text { (CTC) compared to patients without CTC }\end{array}$ & [190] \\
\hline $\operatorname{miR}-210$ & $\begin{array}{l}\text { Higher in patients with residual disease than patients } \\
\text { who achieved pathological complete response; } \\
\text { Correlates with sensitivity to trastuzumab }\end{array}$ & [187] \\
\hline
\end{tabular}


Table 5. Cont.

\begin{tabular}{|c|c|c|}
\hline MicroRNA & Study Findings & References \\
\hline miR-16, miR-21, miR-199a-5p & $\begin{array}{l}\text { Lower in TNBC compared to non-TNBC; } \\
\text { miR-199a-5p associated with tumour stage in TNBC }\end{array}$ & [191] \\
\hline $\operatorname{miR}-373$ & $\begin{array}{l}\text { Exosomal levels higher in TNBC compared to } \\
\text { luminal breast cancer }\end{array}$ & [186] \\
\hline miR-127, miR-197, miR-222, miR-223 & $\begin{array}{l}\text { Target CXCL12; are transposed via gap junctions } \\
\text { from bone marrow to breast cancer cells and also } \\
\text { through exosomes; } \rightarrow \text { leading to cell quiescence, } \\
\text { might contribute to dormancy of bone marrow } \\
\text { metastasis }\end{array}$ & [192] \\
\hline miR-223 & $\begin{array}{l}\text { Macrophages secret microvesicles that contain this } \\
\text { miRNA, promoting cell invasion }\end{array}$ & [193] \\
\hline miR-222 & $\begin{array}{l}\text { Chemoresistance is transmitted between breast } \\
\text { cancer cells via exosomes with specific miRNAs }\end{array}$ & [194] \\
\hline miR-105 & $\begin{array}{l}\text { Is secreted in exosomes from metastatic breast cancer } \\
\text { cells; targets } Z O-1 \text { (tight junction protein) } \rightarrow \\
\text { destroying tight junctions (barrier for metastasis). It's } \\
\text { over-expression induces metastasis }\end{array}$ & [195] \\
\hline miR-155 & $\begin{array}{l}\text { Targets TRF-1 (telomere sheltering function); high } \\
\text { levels are associated with low TRF-1, metastasis-free } \\
\text { survival, and relapse-free survival in ER+ cases. } \\
\text { Reducing miR-155 improves telomere function and } \\
\text { genomic stability }\end{array}$ & [180] \\
\hline
\end{tabular}

\section{5. miRNAs as Therapeutics}

The above mentioned studies clearly show the importance and involvement of miRNAs in cancer initiation, development, and progression and also in chemotherapy resistance. As such, they have become a focus in drug development studies for targeted therapies. Many studies have shown the tumour suppressor or oncogenic functions of miRNAs through knock-downs or overexpression experiments in cell lines and more recently in mice (see Table 2). One of the challenges is the delivery of these miRNAs to the affected tissue, without affecting the healthy tissue. There are multiple challenges for the delivery of miRNAs including biological barriers, toxicity of the miRNA, tissue specificity and the monitoring of the delivery. All of these have been reviewed in [196]. There are different mechanisms for miRNA delivery; earlier methods were based on intravenous injections of anti-miRNA oligonucleotides into mice [197]. Nevertheless, these "naked" oligonucleotides were not stable and were easily degraded by endogenous RNAs. The addition of cholesterol conjugated 2'-O-methyl groups to these oligonucleotides increases their stability and produces what is commonly referred to as an antagomiR. Krutzfeldt et al. were the first to demonstrate the effectiveness of antagomiRs in silencing their target miRNA (miR-16, miR-122, miR-192 and miR-194) in liver, lung, kidney, heart, intestine, fat, skin, bone marrow, muscle, ovaries and adrenals [198]. An antagomir to miR-10b was also shown to inhibit metastatic growth in a mouse mammary tumour model [117]. Further development led to so-called "locked nucleic acid" (LNA) oligomers [199]. These have an increased miRNA binding affinity, greater stability and reduced toxicity due to a ribose moiety that is locked into a C3'-endo conformation via an addition of a methylene bridge [199]. Recently, a study by Xing et al. showed LNA targeting BCAR4 (long-noncoding RNA) strongly suppresses breast cancer metastasis in a mouse model [200]. Another approach is miRNA sponges, which are vector-encoded molecules [201]. The advantage of these sponges is that they contain multiple binding sites, which enables them to inhibit multiple miRNAs simultaneously. Furthermore, they can be stably integrated in the genome and to create stable cell lines or transgenic animal models. Nevertheless, the vector size and poor distribution in the body makes them almost unusable in humans, which explains why there are no breast cancer trials that have used miRNA sponges.

The above methods have shown the progression of developing potential therapeutics which can inhibit oncogenic miRNAs, but there are also several approaches for increasing the levels of tumour-suppressive miRNA. Adeno-associated viruses (AVV) are known to have a high transferring 
ability, low immunorejections and long-term gene expression [202]. miR-26a is a tumour suppressor $\mathrm{miR}$ that is known to be down-regulated in multiple cancers, including breast cancer. It has been shown that over-expression of miR-26a via AVV suppresses tumorigenesis with no signs of hepatoxicity or dysregulation of endogenous miRNAs (murine liver cancer model) [203]. A very recent study by Trepel et al. focused on the systemic delivery of dual-targeted AAV vectors for the treatment of multifocal breast cancer to overcome collateral tropism, which is frequent with the use of AAV vectors [204]. By including miRNA-regulated transgene cassettes they achieved stronger, completely tumour-specific transgene expression. Another method to increase miRNA levels is via nanoparticles, which are small positively charged structures that can be used to transport negatively charged miRNAs to the target tissue [205]. The major advantages of these nanoparticles are that they improve miRNA stability and release the miRNAs slowly for prolonged mRNA targeting, which also helps to avoid possible immunogenicity (associated with AAVs) [206]. Further development of these nanoparticles has made it possible to design multifunctional RNA nanoparticles, as shown in the recent study by Shu et al. [207]. They developed a multifunctional RNA nanoparticle that delivered anti-miR-21, as well as an EGFR targeting aptamer and a fluorescent imaging module (Alexa647) into a TNBC mouse model. The particle bound strongly to the tumour and showed little or no accumulation in healthy tissue eight hours after injection and significantly repressed tumour growth at a low dose. These studies show how research is developing to bring the use of miRNA-based therapies in clinics a realisation. Until this time, further validations and the first breast cancer clinical trials are necessary to enhance the targeting function and decrease possible side effects.

\section{DNA Methylation}

The basis of epigenetic change is centred around the modification of CpG islands, histones and nucleosome positioning. Many cellular processes are influenced by epigenetic change, including gene expression, cellular differentiation, genomic imprinting and embryogenesis [208]. Epigenetic differences can be observed even in genetically identical twins who can suffer from diverse genetically driven diseases, such as cancer, as a result of different DNA methylation profiles [209,210]. Feinberg and Vogelstein were the first to report on epigenetic change in cancer as they found colorectal cancer cells were hypo-methylated compared to normal tissue [211]. DNA hypo-methylation leads to oncogene activation and chromosome instability culminating in tumour development. Conversely, hyper-methylation has been shown to inhibit tumour suppressor genes, thereby releasing cells from their normal physiological control.

DNA methylation is associated with the addition of a methyl group to a cytosine base in DNA and is usually associated with genomic stability, but is also associated with the control of gene expression via an alteration in the transcriptional accessing of transcriptional start sites. Embryonic stem cells use this biochemical process to differentiate into tissue specific cells, which is usually irreversible [212].

DNA methylation mostly occurs on so called CpG islands, which are DNA regions with at least 200 bases that consist of at least 50\% C + G content [213]. The majority of human promoters are associated with CpG islands and are usually unmethylated, only a few become methylated during development or cell differentiation. The DNA methyltransferase (DNMT) converts the cytosine bases into 5-methylcytosine, which generally leads to gene silencing. The different kinds of DNMTs are also necessary to maintain DNA methylation after cells traverse the cell cycle. DNMT1 will copy the methylation pattern and replicate it to the daughter DNA strand and is therefore called a maintenance enzyme [214]. In mammals the enzymes DNMT3a and DNMT3b are responsible for the initial DNA methylation [215]. There are multiple mechanisms in which DNA methylation can inhibit gene expression. It can lead to binding of methyl-CpG-binding domain proteins (MBD), which then recruit histone modifying and/or chromatin remodelling complexes to the methylated site that inhibit gene expression, by forming a more compact and inactive chromatin [216]. DNA methylation can also inhibit the binding of transcription factors to the promoter; nevertheless a recent study suggests that this does not occur frequently $[217,218]$. Recently, it has been shown that not only CpG islands, but 
also CpG shores (regions close to CpG islands with less $C+G$ content) can be methylated, which may be a form of tissue specific methylation and gene expression inhibition [219].

Many gene expression-related diseases, including breast cancer, are affected by DNA methylation. The right level of methylation is especially important during early development to secure key processes like X-chromosome inactivation and genomic imprinting as well as the development of tissue specific cells from embryonic stem cells. Indeed incorrect DNA methylation levels during development can result in disease or death $[214,220]$.

\subsection{Epigenetic Gene Inactivation during Breast Cancer Development and Progression}

Early studies generally focused on known cancer related genes (mostly tumour suppressor genes) as their methylation would lead to gene silencing. An example for this is a study by Berman et al. who identified that $p 16$ is methylated and therefore inactivated in early breast cancer [221]. Another example is the epigenetic inactivation of SLIT3 in 12 out of $29(41 \%)$ breast cancer cell lines and 5 out of $32(16 \%)$ primary tumours [222]. The finding that their promoter methylation results in blocking transcription supports the notion that they are required to inhibit cellular proliferation. Yan et al. took the first global approach of DNA methylation analysis in breast cancer by using CpG island arrays, where 28 breast cancer samples were compared to 28 normal samples to assess their global hypermethylation status and determine if this was associated with tumour grade [223]. They confirmed that $9 \%$ of the tested $1104 \mathrm{CpG}$ sites showed increased methylation in tumour samples compared to the normal samples. DNA methylation has also been used as a marker for breast cancer hormone receptor (HR) expression. The methylation level of ESR1 (gene for ER $\alpha$ ) can be used as a predictor for the PR status and the methylation of PGR (gene for PR) can predict ER status [224]. Genome-wide methylation studies have now been performed by: (1) methylated DNA immunoprecipitation (MDIP) followed by hybridisation to high density oligonucleotide arrays [225], or next generation sequencing [226]; (2) Next-generation genome-wide sequencing of bisulfite-converted DNA [227] and (3) Illumina bead chip arrays (27 K or $450 \mathrm{~K}$ array format) [228].

Multiple studies have aimed at identifying biomarkers for early breast cancer by comparing ductal carcinoma in situ (DCIS) with invasive ductal carcinoma (IDC). This has been reviewed by Pang et al. [229]. Muggerud identified ABCB1, FOXC1, GSTP1, MGMT, MCH1, PPP2R2B, PTEN and $R A S S F 1 A$ as potential biomarkers for early breast cancer detection in DCIS as these genes already show altered methylation in DCIS compared to normal breast tissue, at the same level as in IDCs [230]. Since the review there have been further studies. The methylation of MINT17, MINT31, RARß2, and RASSF1A has been found to increase throughout disease development from normal breast to ductal hyperplasia, to atypical ductal hyperplasia, to DCIS, to IDC [231]. A genome-wide study comparing DCIS and IDC to normal identified 5000 differentially methylated genes comparing normal to DCIS and 1000 genes comparing DCIS to IDC [232]. These markers may provide potential prognostic value for future breast cancer patients.

\subsection{DNA Methylation for Breast Cancer Subtype Classification}

DNA methylation can also be used to improve current breast cancer classification. There is a distinct difference between methylation and gene expression profiles of breast cancer such that not all methylation profiles fit within the same molecular subtype. Nevertheless, this might lead to an improvement of the current classification, which could also improve future treatment options and breast cancer diagnosis/prognosis. Multiple studies used a panel of 807 cancer-related genes to classify breast cancer patients into subtypes by analysing their DNA methylation [233-235]. All three studies support that there is a difference in the epigenetic profile of breast cancer compared to their respective gene expression pattern (defining the molecular subtype). Bediaga et al. identified subtype specific methylation profiles for basal-like, luminal A, and HER2-overexpressing breast cancers [233]. A similar study by Holm divided 189 breast cancer samples into luminal A, luminal B, and basal-like with the methylation profile of 807 cancer-related genes. HER2-enriched and normal-like breast cancers were 
distributed between them [234]. A third study by Ronneberg clustered 80 breast cancer tumours into three groups using the methylation profile of the 807 cancer-related genes. These groups were distinct for ER status, TP53 status, HER2 status and tumour grade [235]. One of the first genome-wide studies to determine whether DNA methylation could be used to classify breast cancer samples into intrinsic subtypes used the MDIP assay on 33 breast cancer samples, to compare genome-wide methylation with the expression of 25,500 transcripts. Again, it confirmed that the epigenetic profile does not necessarily group the samples into the same breast cancer subtypes as gene expression profiling [236]. This study identified an association of the DNA methylation profile with the BRCA status of breast cancer samples. More recently Conway et al. (analysis of 935 CpG sites in 517 breast tumours from the Carolina Breast Cancer Study) identified breast cancer DNA methylation to be associated with hormone receptor status, subtype and TP53 mutation status [237]. It was found that $B C R, C 4 B, D A B 2 I P, M E S T, R A R A$, SEPT5, TFF1, THY1 and SERPINA5 were all hypermethylated in hormone receptor negative, basal-like, and/or TP53 mutated tumours, whereas FABP3, FGF2, FZD9, GAS7, HDAC9, HOXA11, MME, PAX6, POMC, PTGS2, RASSF1, RBP1 and SCGB3A1 were hypermethylated in hormone receptor positive, luminal A and/or p53 wild-type tumours. Earlier this year Stefansson et al. [238] performed Infinium $450 \mathrm{~K}$ arrays on 212 tumours and discovered that luminal B breast cancer show CpG island promoter methylation, whereas basal-like tumours show hypomethylation events in gene bodies. Therefore, they named the two epigenetic breast cancer subtypes Epi-LumB and Epi-Basal, which are also associated with unfavourable clinical parameters and reduced survival [238].

As discussed earlier, there is an urgent need for biomarkers that can be measured by a less invasive technique than from tumour specimens. Circulating miRNAs provide one option but nevertheless, DNA methylation profiles from patient serum may provide an alternative. Even though DNA methylation is cell type specific it is possible to extract circulating tumour cells from serum and perform DNA methylation analysis on them. This has been done by Jing et al. They were able to show that the CIMP ( $\mathrm{CpG}$ island methylator phenotype) is different from patient serum compared to healthy controls [239]. A seven gene hypermethylation profile was identified by Radpour $e t$ al. by comparing triple matched samples from tumour tissue, normal tissue and serum. These seven genes were APC, BIN1, BMP6, BRCA1, CST6, P16 and TIMP3, which were hypermethylated in tumour tissue and serum compared to normal tissue [240]. Nevertheless, further studies are needed to validate these markers and to assess their robustness.

\subsection{DNA Methylation in TNBC}

There have been few studies focusing on DNA methylation in TNBC, and until earlier this year, there were no whole genome DNA methylation analyses. Stirzaker $e t$ al. identified a DNA methylation signature for TNBC patients that divided patients into one of three groups based on their disease outcome (poor, medium, and good) using The Cancer Genome Atlas data (TCGA) [241]. They identified that TNBC patients with low levels of tumour DNA methylation in the gene signature had the best prognosis, followed by high levels of methylation with an intermediate prognosis and lastly, patients whose tumours had medium methylation levels had the worst prognosis. Further to this, they identified a gene methylation signature that separated TNBC from non-TNBC cases [241]. A number of studies have analysed the methylation status of $B R C A 1$, a key player in breast cancer and TNBC. One of the first studies to identify that the BRCA1 promoter was methylated in TNBC came from Veeck et al. [242] in 2010. They suggested that this was a marker for the effectiveness of PARP inhibitors. They showed that the sensitivity of TNBC breast cancer cell lines to PARP inhibitors was increased when BRCA1 was methylated [242]. BRCA1 promoter methylation has also been associated with low expression of $\mathrm{pRb}$ and high expression of $\mathrm{p} 76$ [243]. A study by Watanabe $\mathrm{et}$ al. showed that methylation of the homologous recombination DNA repair genes BRCA1 and RNF8 was significantly higher in TNBCs than luminal breast cancers. At the same time, BRCA1 methylation was higher in patients with pathological complete response than in non-responders to neoadjuvant chemotherapy. The opposite effect was seen for RNF8 [244]. The BRCA1 gene plays an important 
role in breast cancer. TNBC cases have similar histopathological and molecular features as those breast cancers that result from germline BRCA1 mutations. However, only $10 \%-20 \%$ of TNBCs have a $B R C A 1$ mutation, which led Sharma et al. to hypothesise that these similarities are due to epigenetic inactivation of $B R C A 1$ [245]. Within their cohort of 39 TNBC patients, they identified that $30 \%$ of them had $B R C A 1$ promoter methylation, which led to silencing of this gene. Further, they showed that the overall survival for patients with $B R C A 1$ promoter methylation was only $36 \%$, whereas for patients without $B R C A 1$ promotor methylation, the overall survival was $77 \%$ [245]. In contrast to this, $\mathrm{Xu}$ et al. showed that TNBC patients with $B R C A 1$ methylation are more sensitive to adjuvant chemotherapy and that this is associated with better survival when compared to TNBC patients without BRCA1 methylation [246]. Their study showed an increased 10-year disease free survival of $78 \%$ in patients with $B R C A 1$ methylation, compared to $55 \%$ in patients without $B R C A 1$ methylation. The 10 -year disease specific survival also increased in patients with $B R C A 1$ methylation (85\%) compared to patients without $B R C A 1$ methylation (69\%). This was confirmed by Ignatov et al. [247], where they also showed that $B R C A 1$ methylation is only associated with disease-free survival in TNBC but not in non-TNBC cases $(p=0.009$ compared to $p=0.322$ ).

\section{Interactions between miRNAs and Epigenetic Mechanisms}

It has been shown that epigenetic mechanisms of gene inactivation can be controlled by other epigenetic processes. miRNAs have been shown to target DNMT enzymes and influence the DNA methylation process $[248,249]$. On the other hand, important proteins for the biogenesis of miRNAs can be methylated and decrease the number of transcribed miRNAs.

The majority of miRNAs have been found to be located within the intronic regions of protein-coding genes [250], which are so-called host genes, and as such they can be co-regulated [251]. Nevertheless, miRNAs also have their own promoters, which can be near/within CpG islands within the same intron where the miRNA is located. A study by Wee et al. identified that approximately $60 \%$ of 93 breast cancer associated miRNAs are within $5 \mathrm{~kb}$ of a CpG island [252]. This suggests that miRNAs can be transcribed from their own promoter, and that this promoter can be regulated by DNA methylation. This has been shown in multiple cancer studies [253-256]. As an example, Lehmann et al. have shown that miR-9-1, miR-124a3, miR-148, miR-152 and miR-663 are epigenetically inactivated through hyper-methylation in breast cancer [257]. Additionally, miR-31 has been shown to be methylated in TNBC and this leads to an increase in the expression of its pro-metastatic target genes (RhoA and WAVE3) [94].

As mentioned above, miRNAs can also control the epigenetic machinery. Fabbri et al. were the first to identify that the miR-29 family directly targets the DNA methyltransferases DNMT3a and DNMT3b [249]. The miR-29 family is downregulated in lung cancer and DNMT3a and3b are up-regulated, this can be reversed by miR-29 over-expression. This also causes re-expression of methylation-silenced tumour suppressor genes (FHIT, WWOX). Later these miRNAs were referred to as epi-miRs [257]. The miR-148 family can also target DNMT3b, resulting in decreased DNA methylation levels and altered splicing of DNMT3b [248]. Interestingly, as mentioned above, miR-148a is also epigenetically regulated through promoter hyper-methylation [253], suggesting an epigenetic feedback loop. In summary, there are a number of studies focusing on the interaction between epigenetic mechanisms-miRNAs and methylation. A better understanding of these interactions will improve the knowledge of cancer development and progression, which will lead to improved diagnostic and prognostic markers.

\section{Conclusions}

In conclusion, the majority of biomarkers for TNBC have been identified through gene and microRNA expression analysis. There is still a lack of concordance between these studies and limited understanding of the influence that DNA methylation plays in the regulation of TNBC development and progression. There is a need for studies to correlate the findings between miRNA/gene expression 
profiles and epigenetic profiles of TNBC, in order to develop a better understanding of the disease process and identify robust biomarkers.

Acknowledgments: Andrea Mathe is supported by a University Postgraduate Award. This study was funded by the National Breast Cancer Foundation and the Hunter Medical Research Institute, through donations from Hunter Breast Cancer Foundation, and PULSE, as well as a grant supported by Brad Webb and Paul Craven along with the Wests Group Australia.

Author Contributions: Andrea Mathe: concept and writing of manuscript; Rodney J. Scott: obtained funding, critical revision of the manuscript and study supervision; Kelly A. Avery-Kiejda: concept, critical revision of the manuscript, obtained funding and study supervision. All authors have read and approved the final version of this manuscript.

Conflicts of Interest: The authors declare no conflict of interest.

\section{References}

1. Ferlay, J.; Soerjomataram, I.; Dikshit, R.; Eser, S.; Mathers, C.; Rebelo, M.; Parkin, D.M.; Forman, D.; Bray, F. Cancer incidence and mortality worldwide: Sources, methods and major patterns in globocan 2012. Int. J. Cancer 2015, 136, E359-E386. [CrossRef] [PubMed]

2. Den Hollander, P.; Savage, M.I.; Brown, P.H. Targeted therapy for breast cancer prevention. Front. Oncol. 2013, 3. [CrossRef] [PubMed]

3. Maxmen, A. The hard facts. Nature 2012, 485, S50-S51. [CrossRef] [PubMed]

4. Gucalp, A.; Traina, T.A. Triple-negative breast cancer: Adjuvant therapeutic options. Chemother. Res. Pract. 2011, 2011. [CrossRef] [PubMed]

5. Wong-Brown, M.W.; Meldrum, C.J.; Carpenter, J.E.; Clarke, C.L.; Narod, S.A.; Jakubowska, A.; Rudnicka, H.; Lubinski, J.; Scott, R.J. Prevalence of BRCA1 and BRCA2 germline mutations in patients with triple-negative breast cancer. Breast Cancer Res. Treat. 2015, 150, 71-80. [CrossRef] [PubMed]

6. Carey, L.; Winer, E.; Viale, G.; Cameron, D.; Gianni, L. Triple-negative breast cancer: Disease entity or title of convenience? Nat. Rev. Clin. Oncol. 2010, 7, 683-692. [CrossRef] [PubMed]

7. Arnedos, M.; Bihan, C.; Delaloge, S.; Andre, F. Triple-negative breast cancer: Are we making headway at least? Ther. Adv. Med. Oncol. 2012, 4, 195-210. [CrossRef] [PubMed]

8. Sorlie, T.; Perou, C.M.; Tibshirani, R.; Aas, T.; Geisler, S.; Johnsen, H.; Hastie, T.; Eisen, M.B.; van de Rijn, M.; Jeffrey, S.S.; et al. Gene expression patterns of breast carcinomas distinguish tumor subclasses with clinical implications. Proc. Natl. Acad. Sci. USA 2001, 98, 10869-10874. [CrossRef] [PubMed]

9. Bae, S.Y.; Lee, S.K.; Koo, M.Y.; Hur, S.M.; Choi, M.Y.; Cho, D.H.; Kim, S.; Choe, J.H.; Lee, J.E.; Kim, J.H.; et al. The prognoses of metaplastic breast cancer patients compared to those of triple-negative breast cancer patients. Breast Cancer Res. Treat. 2011, 126, 471-478. [CrossRef] [PubMed]

10. Jung, S.Y.; Kim, H.Y.; Nam, B.H.; Min, S.Y.; Lee, S.J;; Park, C.; Kwon, Y.; Kim, E.A.; Ko, K.L.; Shin, K.H.; et al. Worse prognosis of metaplastic breast cancer patients than other patients with triple-negative breast cancer. Breast Cancer Res. Treat. 2010, 120, 627-637. [CrossRef] [PubMed]

11. Honma, N.; Saji, S.; Kurabayashi, R.I.E.; Aida, J.; Arai, T.; Horii, R.I.E.; Akiyama, F.; Iwase, T.; Harada, N.; Younes, M.; et al. Oestrogen receptor- $\beta 1$ but not oestrogen receptor- $\beta c x$ is of prognostic value in apocrine carcinoma of the breast. APMIS 2008, 116, 923-930. [CrossRef] [PubMed]

12. Reis-Filho, J.S.; Tutt, A.N. Triple negative tumours: A critical review. Histopathology 2008, 52, 108-118. [CrossRef] [PubMed]

13. Bauer, K.R.; Brown, M.; Cress, R.D.; Parise, C.A.; Caggiano, V. Descriptive analysis of estrogen receptor (ER)-negative, progesterone receptor (PR)-negative, and HER2-negative invasive breast cancer, the so-called triple-negative phenotype: A population-based study from the california cancer registry. Cancer 2007, 109, 1721-1728. [CrossRef] [PubMed]

14. Dent, R.; Hanna, W.M.; Trudeau, M.; Rawlinson, E.; Sun, P.; Narod, S.A. Pattern of metastatic spread in triple-negative breast cancer. Breast Cancer Res. Treat. 2009, 115, 423-428. [CrossRef] [PubMed]

15. Parvin, F.; Peddi, M.J.E.; Cynthia, M. Molecular basis of triple negative breast cancer and implications for therapy. Int. J. Breast Cancer 2012, 2012. [CrossRef] 
16. Anders, C.K.; Winer, E.P.; Ford, J.M.; Dent, R.; Silver, D.P.; Sledge, G.W.; Carey, L.A. Poly(adp-ribose) polymerase inhibition: "Targeted" therapy for triple-negative breast cancer. Clin. Cancer Res. 2010, 16, 4702-4710. [CrossRef] [PubMed]

17. O'Shaughnessy, J.; Osborne, C.; Pippen, J.E.; Yoffe, M.; Patt, D.; Rocha, C.; Koo, I.C.; Sherman, B.M.; Bradley, C. Iniparib plus chemotherapy in metastatic triple-negative breast cancer. N. Engl. J. Med. 2011, 364, 205-214. [CrossRef] [PubMed]

18. O'Shaughnessy, J.; Schwartzberg, L.; Danso, M.A.; Miller, K.D.; Rugo, H.S.; Neubauer, M.; Robert, N.; Hellerstedt, B.; Saleh, M.; Richards, P.; et al. Phase III study of iniparib plus gemcitabine and carboplatin versus gemcitabine and carboplatin in patients with metastatic triple-negative breast cancer. J. Clin. Oncol. 2014, 32, 3840-3847. [CrossRef] [PubMed]

19. Linderholm, B.K.; Hellborg, H.; Johansson, U.; Elmberger, G.; Skoog, L.; Lehtio, J.; Lewensohn, R. Significantly higher levels of vascular endothelial growth factor (VEGF) and shorter survival times for patients with primary operable triple-negative breast cancer. Ann. Oncol. 2009, 20, 1639-1646. [CrossRef] [PubMed]

20. O'Shaughnessy, J.; Dieras, V.; Glaspy, J.; Brufsky, A.; Miller, K.; Miles, D.; Koralewski, P.; Phan, S.; Bhattacharya, S. Comparison of subgroup analyses of PFS from three phase III studies of bevacizumab in combination with chemotherapy in patients with HER2-negative metastatic breast cancer (MBC). Cancer Res. 2009, 69. [CrossRef]

21. Nielsen, T.O.; Hsu, F.D.; Jensen, K.; Cheang, M.; Karaca, G.; Hu, Z.; Hernandez-Boussard, T.; Livasy, C.; Cowan, D.; Dressler, L.; et al. Immunohistochemical and clinical characterization of the basal-like subtype of invasive breast carcinoma. Clin. Cancer Res. 2004, 10, 5367-5374. [CrossRef] [PubMed]

22. Baselga, J.; Gomez, P.; Greil, R.; Braga, S.; Climent, M.A.; Wardley, A.M.; Kaufman, B.; Stemmer, S.M.; Pego, A.; Chan, A.; et al. Randomized phase II study of the anti-epidermal growth factor receptor monoclonal antibody cetuximab with cisplatin versus cisplatin alone in patients with metastatic triple-negative breast cancer. $J$. Clin. Oncol. 2013, 31, 2586-2592. [CrossRef] [PubMed]

23. Hiscox, S.; Morgan, L.; Green, T.P.; Barrow, D.; Gee, J.; Nicholson, R.I. Elevated SRC activity promotes cellular invasion and motility in tamoxifen resistant breast cancer cells. Breast Cancer Res. Treat. 2006, 97, 263-274. [CrossRef] [PubMed]

24. Finn, R.S. Targeting src in breast cancer. Ann. Oncol. 2008, 19, 1379-1386. [CrossRef] [PubMed]

25. Fornier, M.N.; Morris, P.G.; Abbruzzi, A.; D’Andrea, G.; Gilewski, T.; Bromberg, J.; Dang, C.; Dickler, M.; Modi, S.; Seidman, A.D.; et al. A phase I study of dasatinib and weekly paclitaxel for metastatic breast cancer. Ann. Oncol. 2011, 22, 2575-2581. [CrossRef] [PubMed]

26. Shah, P.D.; Gucalp, A.; Traina, T.A. The role of the androgen receptor in triple-negative breast cancer. Womens Health 2013, 9, 351-360. [CrossRef] [PubMed]

27. Anestis, A.; Karamouzis, M.V.; Dalagiorgou, G.; Papavassiliou, A.G. Is androgen receptor targeting an emerging treatment strategy for triple negative breast cancer? Cancer Treat. Rev. 2015, 41, 547-553. [CrossRef] [PubMed]

28. Gucalp, A.; Tolaney, S.; Isakoff, S.J.; Ingle, J.N.; Liu, M.C.; Carey, L.A.; Blackwell, K.; Rugo, H.; Nabell, L.; Forero, A.; et al. Phase II trial of bicalutamide in patients with androgen receptor-positive, estrogen receptor-negative metastatic breast cancer. Clin. Cancer Res. 2013, 19, 5505-5512. [CrossRef] [PubMed]

29. Petrelli, F.; Coinu, A.; Borgonovo, K.; Cabiddu, M.; Ghilardi, M.; Lonati, V.; Barni, S. The value of platinum agents as neoadjuvant chemotherapy in triple-negative breast cancers: A systematic review and meta-analysis. Breast Cancer Res. Treat. 2014, 144, 223-232. [CrossRef] [PubMed]

30. Perou, C.M.; Sorlie, T.; Eisen, M.B.; van de Rijn, M.; Jeffrey, S.S.; Rees, C.A.; Pollack, J.R.; Ross, D.T.; Johnsen, H.; Akslen, L.A.; et al. Molecular portraits of human breast tumours. Nature 2000, 406, 747-752. [CrossRef] [PubMed]

31. Eroles, P.; Bosch, A.; Alejandro Pérez-Fidalgo, J.; Lluch, A. Molecular biology in breast cancer: Intrinsic subtypes and signaling pathways. Cancer Treat. Rev. 2011, 38, 698-707. [CrossRef] [PubMed]

32. Prat, A.; Perou, C.M. Deconstructing the molecular portraits of breast cancer. Mol. Oncol. 2011, 5, 5-23. [CrossRef] [PubMed]

33. Curtis, C.; Shah, S.P.; Chin, S.F.; Turashvili, G.; Rueda, O.M.; Dunning, M.J.; Speed, D.; Lynch, A.G.; Samarajiwa, S.; Yuan, Y.; et al. The genomic and transcriptomic architecture of 2000 breast tumours reveals novel subgroups. Nature 2012, 486, 346-352. [PubMed] 
34. Lehmann, B.D.; Bauer, J.A.; Chen, X.; Sanders, M.E.; Chakravarthy, A.B.; Shyr, Y.; Pietenpol, J.A. Identification of human triple-negative breast cancer subtypes and preclinical models for selection of targeted therapies. J. Clin. Investig. 2011, 121, 2750-2767. [CrossRef] [PubMed]

35. Burstein, M.D.; Tsimelzon, A.; Poage, G.M.; Covington, K.R.; Contreras, A.; Fuqua, S.A.; Savage, M.I.; Osborne, C.K.; Hilsenbeck, S.G.; Chang, J.C.; et al. Comprehensive genomic analysis identifies novel subtypes and targets of triple-negative breast cancer. Clin. Cancer Res. 2015, 21, 1688-1698. [CrossRef] [PubMed]

36. Prat, A.; Lluch, A.; Albanell, J.; Barry, W.T.; Fan, C.; Chacon, J.I.; Parker, J.S.; Calvo, L.; Plazaola, A.; Arcusa, A.; et al. Predicting response and survival in chemotherapy-treated triple-negative breast cancer. Br. J. Cancer 2014, 111, 1532-1541. [CrossRef] [PubMed]

37. Campone, M.; Valo, I.; Jezequel, P.; Moreau, M.; Boissard, A.; Campion, L.; Loussouarn, D.; Verriele, V.; Coqueret, O.; Guette, C. Prediction of recurrence and survival for triple-negative breast cancer by a protein signature in tissue samples. Mol. Cell. Proteom. 2015, 14, 2936-2946. [CrossRef] [PubMed]

38. Shen, S.; Sun, Q.; Liang, Z.; Cui, X.; Ren, X.; Chen, H.; Zhang, X.; Zhou, Y. A prognostic model of triple-negative breast cancer based on miR-27b-3p and node status. PLoS ONE 2014, 9, e100664. [CrossRef] [PubMed]

39. Atkinson, R.L.; Yang, W.T.; Rosen, D.G.; Landis, M.D.; Wong, H.; Lewis, M.T.; Creighton, C.J.; Sexton, K.R.; Hilsenbeck, S.G.; Sahin, A.A.; et al. Cancer stem cell markers are enriched in normal tissue adjacent to triple negative breast cancer and inversely correlated with DNA repair deficiency. Breast Cancer Res. 2013, 15. [CrossRef] [PubMed]

40. Braakhuis, B.J.; Leemans, C.R.; Brakenhoff, R.H. Using tissue adjacent to carcinoma as a normal control: An obvious but questionable practice. J. Pathol. 2004, 203, 620-621. [CrossRef] [PubMed]

41. Waddington, C.H. The epigenotype. Endeavour 1942, 1, 18-20. [CrossRef] [PubMed]

42. Holliday, R. The inheritance of epigenetic defects. Science 1987, 238, 163-170. [CrossRef] [PubMed]

43. Virani, S.; Colacino, J.A.; Kim, J.H.; Rozek, L.S. Cancer epigenetics: A brief review. ILAR J. 2012, 53, 359-369. [CrossRef] [PubMed]

44. Lee, R.C.; Feinbaum, R.L.; Ambros, V. The C. elegans heterochronic gene lin-4 encodes small RNAs with antisense complementarity to lin-14. Cell 1993, 75, 843-854. [CrossRef]

45. Beezhold, K.J.; Castranova, V.; Chen, F. Microprocessor of microRNAs: Regulation and potential for therapeutic intervention. Mol. Cancer 2010, 9. [CrossRef] [PubMed]

46. Calin, G.A.; Croce, C.M. MicroRNA signatures in human cancers. Nat. Rev. Cancer 2006, 6, 857-866. [CrossRef] [PubMed]

47. O'Connell, R.M.; Rao, D.S.; Chaudhuri, A.A.; Baltimore, D. Physiological and pathological roles for microRNAs in the immune system. Nat. Rev. Immunol. 2010, 10, 111-122. [CrossRef] [PubMed]

48. Kozomara, A.; Griffiths-Jones, S. miRBase: Annotating high confidence microRNAs using deep sequencing data. Nucleic Acids Res. 2014, 42, D68-D73. [CrossRef] [PubMed]

49. Andorfer, C.A.; Necela, B.M.; Thompson, E.A.; Perez, E.A. MicroRNA signatures: Clinical biomarkers for the diagnosis and treatment of breast cancer. Trends Mol. Med. 2011, 17, 313-319. [CrossRef] [PubMed]

50. Friedman, R.C.; Farh, K.K.; Burge, C.B.; Bartel, D.P. Most mammalian mRNAs are conserved targets of microRNAs. Genome Res. 2009, 19, 92-105. [CrossRef] [PubMed]

51. Ha, M.; Kim, V.N. Regulation of microRNA biogenesis. Nat. Rev. Mol. Cell Biol. 2014, 15, 509-524. [CrossRef] [PubMed]

52. O'Day, E.; Lal, A. MicroRNAs and their target gene networks in breast cancer. Breast Cancer Res. $2010,12$. [CrossRef] [PubMed]

53. Ying, S.Y.; Chang, D.C.; Lin, S.L. The microRNA (miRNA): Overview of the RNA genes that modulate gene function. Mol. Biotechnol. 2008, 38, 257-268. [CrossRef] [PubMed]

54. Winter, J.; Diederichs, S. MicroRNA biogenesis and cancer. Methods Mol. Biol. 2011, 676, 3-22. [PubMed]

55. McDaneld, T.G. MicroRNA: Mechanism of gene regulation and application to livestock. J. Anim. Sci. 2009, 87, E21-E28. [CrossRef] [PubMed]

56. Rusk, N. When microRNAs activate translation. Nat. Methods 2008, 5, 122-123. [CrossRef]

57. Calin, G.A.; Dumitru, C.D.; Shimizu, M.; Bichi, R.; Zupo, S.; Noch, E.; Aldler, H.; Rattan, S.; Keating, M.; Rai, K.; et al. Frequent deletions and down-regulation of micro-RNA genes miR15 and miR16 at 13q14 in chronic lymphocytic leukemia. Proc. Natl. Acad. Sci. USA 2002, 99, 15524-15529. [CrossRef] [PubMed] 
58. Voorhoeve, P.M. MicroRNAs: Oncogenes, tumor suppressors or master regulators of cancer heterogeneity? Biochim. Biophys. Acta 2010, 1805, 72-86. [CrossRef] [PubMed]

59. Izumiya, M.; Tsuchiya, N.; Okamoto, K.; Nakagama, H. Systematic exploration of cancer-associated microRNA through functional screening assays. Cancer Sci. 2011, 102, 1615-1621. [CrossRef] [PubMed]

60. Baffa, R.; Fassan, M.; Volinia, S.; O’Hara, B.; Liu, C.G.; Palazzo, J.P.; Gardiman, M.; Rugge, M.; Gomella, L.G.; Croce, C.M.; et al. MicroRNA expression profiling of human metastatic cancers identifies cancer gene targets. J. Pathol. 2009, 219, 214-221. [CrossRef] [PubMed]

61. Di Leva, G.; Briskin, D.; Croce, C.M. MicroRNA in cancer: New hopes for antineoplastic chemotherapy. Ups. J. Med. Sci. 2012, 117, 202-216. [CrossRef] [PubMed]

62. Heneghan, H.M.; Miller, N.; Lowery, A.J.; Sweeney, K.J.; Kerin, M.J. MicroRNAs as novel biomarkers for breast cancer. J. Oncol. 2009, 2009. [CrossRef] [PubMed]

63. Jeffrey, S.S. Cancer biomarker profiling with microRNAs. Nat. Biotechnol. 2008, 26, 400-401. [CrossRef] [PubMed]

64. Avery-Kiejda, K.A.; Braye, S.G.; Mathe, A.; Forbes, J.F.; Scott, R.J. Decreased expression of key tumour suppressor microRNAs is associated with lymph node metastases in triple negative breast cancer. BMC Cancer 2014, 14. [CrossRef] [PubMed]

65. Cascione, L.; Gasparini, P.; Lovat, F.; Carasi, S.; Pulvirenti, A.; Ferro, A.; Alder, H.; He, G.; Vecchione, A.; Croce, C.M.; et al. Integrated microRNA and mRNA signatures associated with survival in triple negative breast cancer. PLoS ONE 2013, 8, e55910. [CrossRef] [PubMed]

66. Aydogdu, E.; Katchy, A.; Tsouko, E.; Lin, C.Y.; Haldosen, L.A.; Helguero, L.; Williams, C. MicroRNA-regulated gene networks during mammary cell differentiation are associated with breast cancer. Carcinogenesis 2012, 33, 1502-1511. [CrossRef] [PubMed]

67. Gregory, P.A.; Bracken, C.P.; Bert, A.G.; Goodall, G.J. MicroRNAs as regulators of epithelial-mesenchymal transition. Cell Cycle 2008, 7, 3112-3118. [CrossRef] [PubMed]

68. Howe, E.N.; Cochrane, D.R.; Richer, J.K. Targets of miR-200c mediate suppression of cell motility and anoikis resistance. Breast Cancer Res. 2011, 13. [CrossRef] [PubMed]

69. Ren, Y.; Han, X.; Yu, K.; Sun, S.; Zhen, L.; Li, Z.; Wang, S. MicroRNA-200c downregulates XIAP expression to suppress proliferation and promote apoptosis of triple-negative breast cancer cells. Mol. Med. Rep. 2014, 10, 315-321. [CrossRef] [PubMed]

70. Lowery, A.J.; Miller, N.; Devaney, A.; McNeill, R.E.; Davoren, P.A.; Lemetre, C.; Benes, V.; Schmidt, S.; Blake, J.; Ball, G.; et al. MicroRNA signatures predict oestrogen receptor, progesterone receptor and HER2/neu receptor status in breast cancer. Breast Cancer Res. 2009, 11. [CrossRef] [PubMed]

71. Janssen, E.A.; Slewa, A.; Gudlaugsson, E.; Jonsdottir, K.; Skaland, I.; Soiland, H.; Baak, J.P. Biologic profiling of lymph node negative breast cancers by means of microRNA expression. Mod. Pathol. 2010, 23, 1567-1576. [CrossRef] [PubMed]

72. Sempere, L.F.; Christensen, M.; Silahtaroglu, A.; Bak, M.; Heath, C.V.; Schwartz, G.; Wells, W.; Kauppinen, S.; Cole, C.N. Altered microRNA expression confined to specific epithelial cell subpopulations in breast cancer. Cancer Res. 2007, 67, 11612-11620. [CrossRef] [PubMed]

73. De Rinaldis, E.; Gazinska, P.; Mera, A.; Modrusan, Z.; Fedorowicz, G.M.; Burford, B.; Gillett, C.; Marra, P.; Grigoriadis, A.; Dornan, D.; et al. Integrated genomic analysis of triple-negative breast cancers reveals novel microRNAs associated with clinical and molecular phenotypes and sheds light on the pathways they control. BMC Genom. 2013, 14. [CrossRef] [PubMed]

74. Kolacinska, A.; Morawiec, J.; Pawlowska, Z.; Szemraj, J.; Szymanska, B.; Malachowska, B.; Morawiec, Z.; Morawiec-Sztandera, A.; Pakula, L.; Kubiak, R.; et al. Association of microRNA-93, 190, 200b and receptor status in core biopsies from stage III breast cancer patients. DNA Cell Biol. 2014, 33, 624-629. [CrossRef] [PubMed]

75. Berber, U.; Yilmaz, I.; Narli, G.; Haholu, A.; Kucukodaci, Z.; Demirel, D. miR-205 and miR-200c: Predictive micro RNAs for lymph node metastasis in triple negative breast cancer. J. Breast Cancer 2014, 17, 143-148. [CrossRef] [PubMed]

76. Chen, W.; Cai, F.; Zhang, B.; Barekati, Z.; Zhong, X.Y. The level of circulating miRNA-10b and miRNA-373 in detecting lymph node metastasis of breast cancer: Potential biomarkers. Tumour Biol. 2013, 34, 455-462. [CrossRef] [PubMed] 
77. Piovan, C.; Palmieri, D.; di Leva, G.; Braccioli, L.; Casalini, P.; Nuovo, G.; Tortoreto, M.; Sasso, M.; Plantamura, I.; Triulzi, T.; et al. Oncosuppressive role of p53-induced miR-205 in triple negative breast cancer. Mol. Oncol. 2012, 6, 458-472. [CrossRef] [PubMed]

78. Wang, C.; Zheng, X.; Shen, C.; Shi, Y. MicroRNA-203 suppresses cell proliferation and migration by targeting BIRC5 and LASP1 in human triple-negative breast cancer cells. J. Exp. Clin. Cancer Res. 2012, 31. [CrossRef] [PubMed]

79. Koerner, C.; Keklikoglou, I.; Bender, C.; Woerner, A.; Muenstermann, E.; Wiemann, S. MicroRNA-31 sensitizes human breast cells to apoptosis by direct targeting of protein kinase C epsilon (PKCepsilon). J. Biol. Chem. 2013, 288, 8750-8761. [CrossRef] [PubMed]

80. Sossey-Alaoui, K.; Downs-Kelly, E.; Das, M.; Izem, L.; Tubbs, R.; Plow, E.F. Wave3, an actin remodeling protein, is regulated by the metastasis suppressor microRNA, miR-31, during the invasion-metastasis cascade. Int. J. Cancer 2011, 129, 1331-1343. [CrossRef] [PubMed]

81. Mackiewicz, M.; Huppi, K.; Pitt, J.J.; Dorsey, T.H.; Ambs, S.; Caplen, N.J. Identification of the receptor tyrosine kinase AXL in breast cancer as a target for the human miR-34a microRNA. Breast Cancer Res. Treat. 2011, 130, 663-679. [CrossRef] [PubMed]

82. Bisso, A.; Faleschini, M.; Zampa, F.; Capaci, V.; de Santa, J.; Santarpia, L.; Piazza, S.; Cappelletti, V.; Daidone, M.; Agami, R.; et al. Oncogenic miR-181a/b affect the DNA damage response in aggressive breast cancer. Cell Cycle 2013, 12, 1679-1687. [CrossRef] [PubMed]

83. Taylor, M.A.; Sossey-Alaoui, K.; Thompson, C.L.; Danielpour, D.; Schiemann, W.P. TGF- $\beta$ upregulates mir-181a expression to promote breast cancer metastasis. J. Clin. Investig. 2013, 123, 150-163. [CrossRef] [PubMed]

84. Garcia, A.I.; Buisson, M.; Bertrand, P.; Rimokh, R.; Rouleau, E.; Lopez, B.S.; Lidereau, R.; Mikaelian, I.; Mazoyer, S. Down-regulation of BRCA1 expression by miR-146a and miR-146b-5p in triple negative sporadic breast cancers. EMBO Mol. Med. 2011, 3, 279-290. [CrossRef] [PubMed]

85. Liu, H.; Wang, Y.; Li, X.; Zhang, Y.-J.; Li, J.; Zheng, Y.-Q.; Liu, M.; Song, X.; Li, X.-R. Expression and regulatory function of miRNA-182 in triple-negative breast cancer cells through its targeting of profilin 1. Tumor Biol. 2013, 34, 1713-1722. [CrossRef] [PubMed]

86. Burk, U.; Schubert, J.; Wellner, U.; Schmalhofer, O.; Vincan, E.; Spaderna, S.; Brabletz, T. A reciprocal repression between ZEB1 and members of the miR-200 family promotes EMT and invasion in cancer cells. EMBO Rep. 2008, 9, 582-589. [CrossRef] [PubMed]

87. Chen, J.; Tian, W.; Cai, H.; He, H.; Deng, Y. Down-regulation of microRNA-200c is associated with drug resistance in human breast cancer. Med. Oncol. 2012, 29, 2527-2534. [CrossRef] [PubMed]

88. Korpal, M.; Lee, E.S.; Hu, G.; Kang, Y. The miR-200 family inhibits epithelial-mesenchymal transition and cancer cell migration by direct targeting of E-cadherin transcriptional repressors ZEB1 and ZEB2. J. Biol. Chem. 2008, 283, 14910-14914. [CrossRef] [PubMed]

89. Lin, J.; Liu, C.; Gao, F.; Mitchel, R.E.; Zhao, L.; Yang, Y.; Lei, J.; Cai, J. miR-200c enhances radiosensitivity of human breast cancer cells. J. Cell. Biochem. 2013, 114, 606-615. [CrossRef] [PubMed]

90. Boyerinas, B.; Park, S.M.; Hau, A.; Murmann, A.E.; Peter, M.E. The role of let-7 in cell differentiation and cancer. Endocr. Relat. Cancer 2010, 17, F19-F36. [CrossRef] [PubMed]

91. Bussing, I.; Slack, F.J.; Grosshans, H. Let-7 microRNAs in development, stem cells and cancer. Trends Mol. Med. 2008, 14, 400-409. [CrossRef] [PubMed]

92. Liu, X.; Gu, X.; Sun, L.; Flowers, A.B.; Rademaker, A.W.; Zhou, Y.; Kiyokawa, H. Downregulation of Smurf2, a tumor-suppressive ubiquitin ligase, in triple-negative breast cancers: Involvement of the RB-microRNA axis. BMC Cancer 2014, 14. [CrossRef] [PubMed]

93. Nassirpour, R.; Mehta, P.P.; Baxi, S.M.; Yin, M.J. miR-221 promotes tumorigenesis in human triple negative breast cancer cells. PLoS ONE 2013, 8, e62170. [CrossRef] [PubMed]

94. Augoff, K.; McCue, B.; Plow, E.F.; Sossey-Alaoui, K. miR-31 and its host gene LncRNA LOC554202 are regulated by promoter hypermethylation in triple-negative breast cancer. Mol. Cancer 2012, 11. [CrossRef] [PubMed]

95. Humphries, B.; Wang, Z.; Oom, A.L.; Fisher, T.; Tan, D.; Cui, Y.; Jiang, Y.; Yang, C. MicroRNA-200b targets protein kinase $\mathrm{C} \alpha$ and suppresses triple-negative breast cancer metastasis. Carcinogenesis 2014, 35, 2254-2263. [CrossRef] [PubMed] 
96. Gan, R.; Yang, Y.; Yang, X.; Zhao, L.; Lu, J.; Meng, Q.H. Downregulation of miR-221/222 enhances sensitivity of breast cancer cells to tamoxifen through upregulation of TIMP3. Cancer Gene Ther. 2014, 21, 290-296. [CrossRef] [PubMed]

97. Rao, X.; di Leva, G.; Li, M.; Fang, F.; Devlin, C.; Hartman-Frey, C.; Burow, M.E.; Ivan, M.; Croce, C.M.; Nephew, K.P. MicroRNA-221/222 confers breast cancer fulvestrant resistance by regulating multiple signaling pathways. Oncogene 2011, 30, 1082-1097. [CrossRef] [PubMed]

98. Xiong, J.; Yu, D.; Wei, N.; Fu, H.; Cai, T.; Huang, Y.; Wu, C.; Zheng, X.; Du, Q.; Lin, D.; et al. An estrogen receptor $\alpha$ suppressor, microRNA-22, is downregulated in estrogen receptor alpha-positive human breast cancer cell lines and clinical samples. FEBS J. 2010, 277, 1684-1694. [CrossRef] [PubMed]

99. Yoshimoto, N.; Toyama, T.; Takahashi, S.; Sugiura, H.; Endo, Y.; Iwasa, M.; Fujii, Y.; Yamashita, H. Distinct expressions of microRNAs that directly target estrogen receptor $\alpha$ in human breast cancer. Breast Cancer Res. Treat. 2011, 130, 331-339. [CrossRef] [PubMed]

100. Fang, C.; Zhao, Y.; Guo, B. MiR-199b-5p targets HER2 in breast cancer cells. J. Cell. Biochem. 2013, 114, 1457-1463. [CrossRef] [PubMed]

101. Leivonen, S.K.; Sahlberg, K.K.; Makela, R.; Due, E.U.; Kallioniemi, O.; Borresen-Dale, A.L.; Perala, M. High-throughput screens identify microRNAs essential for HER2 positive breast cancer cell growth. Mol. Oncol. 2014, 8, 93-104. [CrossRef] [PubMed]

102. Scott, G.K.; Goga, A.; Bhaumik, D.; Berger, C.E.; Sullivan, C.S.; Benz, C.C. Coordinate suppression of ERBB2 and ERBB3 by enforced expression of micro-RNA miR-125a or miR-125b. J. Biol. Chem. 2007, 282, 1479-1486. [CrossRef] [PubMed]

103. Ell, B.; Qiu, Q.; Wei, Y.; Mercatali, L.; Ibrahim, T.; Amadori, D.; Kang, Y. The microRNA-23b/27b/24 cluster promotes breast cancer lung metastasis by targeting metastasis-suppressive gene prosaposin. J. Biol. Chem. 2014, 289, 21888-21895. [CrossRef] [PubMed]

104. Radojicic, J.; Zaravinos, A.; Vrekoussis, T.; Kafousi, M.; Spandidos, D.A.; Stathopoulos, E.N. MicroRNA expression analysis in triple-negative (ER, PR and HER2/neu) breast cancer. Cell Cycle 2011, 10, 507-517. [CrossRef] [PubMed]

105. Chang, S.; Wang, R.H.; Akagi, K.; Kim, K.A.; Martin, B.K.; Cavallone, L.; Kathleen Cuningham Foundation Consortium for Research into Familial Breast Cancer; Haines, D.C.; Basik, M.; Mai, P.; et al. Tumor suppressor BRCA1 epigenetically controls oncogenic microRNA-155. Nat. Med. 2011, 17, 1275-1282. [CrossRef] [PubMed]

106. Foekens, J.A.; Sieuwerts, A.M.; Smid, M.; Look, M.P.; de Weerd, V.; Boersma, A.W.; Klijn, J.G.; Wiemer, E.A.; Martens, J.W. Four miRNAs associated with aggressiveness of lymph node-negative, estrogen receptor-positive human breast cancer. Proc. Natl. Acad. Sci. USA 2008, 105, 13021-13026. [CrossRef] [PubMed]

107. Toyama, T.; Kondo, N.; Endo, Y.; Sugiura, H.; Yoshimoto, N.; Iwasa, M.; Takahashi, S.; Fujii, Y.; Yamashita, H. High expression of microRNA-210 is an independent factor indicating a poor prognosis in Japanese triple-negative breast cancer patients. Jpn. J. Clin. Oncol. 2012, 42, 256-263. [CrossRef] [PubMed]

108. Svoboda, M.; Sana, J.; Redova, M.; Navratil, J.; Palacova, M.; Fabian, P.; Slaby, O.; Vyzula, R. mir-34b is associated with clinical outcome in triple-negative breast cancer patients. Diagn. Pathol. 2012, 7. [CrossRef] [PubMed]

109. Yamakuchi, M.; Lowenstein, C.J. miR-34, SIRT1 and p53: The feedback loop. Cell Cycle 2009, 8, $712-715$. [CrossRef] [PubMed]

110. Buffa, F.M.; Camps, C.; Winchester, L.; Snell, C.E.; Gee, H.E.; Sheldon, H.; Taylor, M.; Harris, A.L.; Ragoussis, J. MicroRNA-associated progression pathways and potential therapeutic targets identified by integrated mrna and microRNA expression profiling in breast cancer. Cancer Res. 2011, 71, 5635-5645. [CrossRef] [PubMed]

111. Dong, G.; Liang, X.; Wang, D.; Gao, H.; Wang, L.; Wang, L.; Liu, J.; Du, Z. High expression of miR-21 in triple-negative breast cancers was correlated with a poor prognosis and promoted tumor cell in vitro proliferation. Med. Oncol. 2014, 31. [CrossRef] [PubMed]

112. MacKenzie, T.A.; Schwartz, G.N.; Calderone, H.M.; Graveel, C.R.; Winn, M.E.; Hostetter, G.; Wells, W.A.; Sempere, L.F. Stromal expression of miR-21 identifies high-risk group in triple-negative breast cancer. Am. J. Pathol. 2014, 184, 3217-3225. [CrossRef] [PubMed]

113. Kong, W.; He, L.; Richards, E.J.; Challa, S.; Xu, C.X.; Permuth-Wey, J.; Lancaster, J.M.; Coppola, D.; Sellers, T.A.; Djeu, J.Y.; et al. Upregulation of miRNA-155 promotes tumour angiogenesis by targeting VHL and is 
associated with poor prognosis and triple-negative breast cancer. Oncogene 2014, 33, 679-689. [CrossRef] [PubMed]

114. Kolacinska, A.; Morawiec, J.; Fendler, W.; Malachowska, B.; Morawiec, Z.; Szemraj, J.; Pawlowska, Z.; Chowdhury, D.; Choi, Y.E.; Kubiak, R.; et al. Association of microRNAs and pathologic response to preoperative chemotherapy in triple negative breast cancer: Preliminary report. Mol. Biol. Rep. 2014, 41, 2851-2857. [CrossRef] [PubMed]

115. Ouyang, M.; Li, Y.; Ye, S.; Ma, J.; Lu, L.; Lv, W.; Chang, G.; Li, X.; Li, Q.; Wang, S.; et al. MicroRNA profiling implies new markers of chemoresistance of triple-negative breast cancer. PLoS ONE 2014, 9, e96228. [CrossRef] [PubMed]

116. Gasparini, P.; Cascione, L.; Fassan, M.; Lovat, F.; Guler, G.; Balci, S.; Irkkan, C.; Morrison, C.; Croce, C.M.; Shapiro, C.L.; et al. MicroRNA expression profiling identifies a four microRNA signature as a novel diagnostic and prognostic biomarker in triple negative breast cancers. Oncotarget 2014, 5, 1174-1184. [CrossRef] [PubMed]

117. Ma, L.; Reinhardt, F.; Pan, E.; Soutschek, J.; Bhat, B.; Marcusson, E.G.; Teruya-Feldstein, J.; Bell, G.W.; Weinberg, R.A. Therapeutic silencing of miR-10b inhibits metastasis in a mouse mammary tumor model. Nat. Biotechnol. 2010, 28, 341-347. [CrossRef] [PubMed]

118. Ma, L.; Teruya-Feldstein, J.; Weinberg, R.A. Tumour invasion and metastasis initiated by microRNA-10b in breast cancer. Nature 2007, 449, 682-688. [CrossRef]

119. Parrella, P.; Barbano, R.; Pasculli, B.; Fontana, A.; Copetti, M.; Valori, V.M.; Poeta, M.L.; Perrone, G.; Righi, D.; Castelvetere, M.; et al. Evaluation of microRNA-10b prognostic significance in a prospective cohort of breast cancer patients. Mol. Cancer 2014, 13. [CrossRef] [PubMed]

120. Liu, Y.; Cai, Q.; Bao, P.P.; Su, Y.; Cai, H.; Wu, J.; Ye, F.; Guo, X.; Zheng, W.; Zheng, Y.; et al. Tumor tissue microRNA expression in association with triple-negative breast cancer outcomes. Breast Cancer Res. Treat. 2015, 152, 183-191. [CrossRef] [PubMed]

121. Kong, D.; Li, Y.; Wang, Z.; Sarkar, F. Cancer stem cells and epithelial-to-mesenchymal transition (EMT)-phenotypic cells: Are they cousins or twins? Cancers 2011, 3, 716-729. [CrossRef] [PubMed]

122. Kalluri, R.; Weinberg, R.A. The basics of epithelial-mesenchymal transition. J. Clin. Investig. 2009, 119, 1420-1428. [CrossRef] [PubMed]

123. Galliher, A.J.; Schiemann, W.P. $\beta_{3}$ integrin and Src facilitate transforming growth factor- $\beta$ mediated induction of epithelial-mesenchymal transition in mammary epithelial cells. Breast Cancer Res. BCR 2006, 8. [CrossRef] [PubMed]

124. Watanabe, S.; Ueda, Y.; Akaboshi, S.; Hino, Y.; Sekita, Y.; Nakao, M. HMGA2 maintains oncogenic RAS-induced epithelial-mesenchymal transition in human pancreatic cancer cells. Am. J. Pathol. 2009, 174, 854-868. [CrossRef] [PubMed]

125. Taki, M.; Verschueren, K.; Yokoyama, K.; Nagayama, M.; Kamata, N. Involvement of ETS-1 transcription factor in inducing matrix metalloproteinase-2 expression by epithelial-mesenchymal transition in human squamous carcinoma cells. Int. J. Oncol. 2006, 28, 487-496. [CrossRef] [PubMed]

126. Mamuya, F.A.; Duncan, M.K. aV integrins and TGF- $\beta$-induced EMT: A circle of regulation. J. Cell. Mol. Med. 2012, 16, 445-455. [CrossRef] [PubMed]

127. Borok, Z. Role for $\alpha 3$ integrin in EMT and pulmonary fibrosis. J. Clin. Investig. 2009, 119, 7-10. [CrossRef] [PubMed]

128. Van der Velden, J.L.; Guala, A.S.; Leggett, S.E.; Sluimer, J.; Badura, E.C.; Janssen-Heininger, Y.M. Induction of a mesenchymal expression program in lung epithelial cells by Wnt/ $\beta$-catenin requires the presence of c-Jun N-terminal kinase 1. Am. J. Respir. Cell Mol. Biol. 2012, 47, 306-314. [CrossRef] [PubMed]

129. Bao, B.; Wang, Z.; Ali, S.; Kong, D.; Li, Y.; Ahmad, A.; Banerjee, S.; Azmi, A.S.; Miele, L.; Sarkar, F.H. Notch-1 induces epithelial-mesenchymal transition consistent with cancer stem cell phenotype in pancreatic cancer cells. Cancer Lett. 2011, 307, 26-36. [CrossRef] [PubMed]

130. Ahmad, A.; Sarkar, S.H.; Bitar, B.; Ali, S.; Aboukameel, A.; Sethi, S.; Li, Y.; Bao, B.; Kong, D.; Banerjee, S.; et al. Garcinol regulates EMT and Wnt signaling pathways in vitro and in vivo leading to anticancer activity against breast cancer cells. Mol. Cancer Ther. 2012, 11, 2193-2201. [CrossRef] [PubMed]

131. Cao, M.; Seike, M.; Soeno, C.; Mizutani, H.; Kitamura, K.; Minegishi, Y.; Noro, R.; Yoshimura, A.; Cai, L.; Gemma, A. MiR-23a regulates TGF- $\beta$-induced epithelial-mesenchymal transition by targeting E-cadherin in lung cancer cells. Int. J. Oncol. 2012, 41, 869-875. [PubMed] 
132. Ceppi, P.; Mudduluru, G.; Kumarswamy, R.; Rapa, I.; Scagliotti, G.V.; Papotti, M.; Allgayer, H. Loss of miR-200c expression induces an aggressive, invasive, and chemoresistant phenotype in non-small cell lung cancer. Mol. Cancer Res. 2010, 8, 1207-1216. [CrossRef] [PubMed]

133. Dong, P.; Karaayvaz, M.; Jia, N.; Kaneuchi, M.; Hamada, J.; Watari, H.; Sudo, S.; Ju, J.; Sakuragi, N. Mutant p53 gain-of-function induces epithelial-mesenchymal transition through modulation of the miR-130b-ZEB1 axis. Oncogene 2012. [CrossRef] [PubMed]

134. Han, M.; Liu, M.; Wang, Y.; Chen, X.; Xu, J.; Sun, Y.; Zhao, L.; Qu, H.; Fan, Y.; Wu, C. Antagonism of miR-21 reverses epithelial-mesenchymal transition and cancer stem cell phenotype through AKT/ERK1/2 inactivation by targeting pten. PLOS ONE 2012, 7, e39520. [CrossRef] [PubMed]

135. Howe, E.N.; Cochrane, D.R.; Richer, J.K. The miR-200 and miR-221/222 microRNA families: Opposing effects on epithelial identity. J. Mammary Gland Biol. Neoplasia 2012, 17, 65-77. [CrossRef] [PubMed]

136. Hur, K.; Toiyama, Y.; Takahashi, M.; Balaguer, F.; Nagasaka, T.; Koike, J.; Hemmi, H.; Koi, M.; Boland, C.R.; Goel, A. MicroRNA-200c modulates epithelial-to-mesenchymal transition (EMT) in human colorectal cancer metastasis. Gut 2013, 62, 1315-1326. [CrossRef] [PubMed]

137. Sarrio, D.; Rodriguez-Pinilla, S.M.; Hardisson, D.; Cano, A.; Moreno-Bueno, G.; Palacios, J. Epithelial-mesenchymal transition in breast cancer relates to the basal-like phenotype. Cancer Res. 2008, 68, 989-997. [CrossRef] [PubMed]

138. Castilla, M.A.; Diaz-Martin, J.; Sarrio, D.; Romero-Perez, L.; Lopez-Garcia, M.A.; Vieites, B.; Biscuola, M.; Ramiro-Fuentes, S.; Isacke, C.M.; Palacios, J. MicroRNA-200 family modulation in distinct breast cancer phenotypes. PLoS ONE 2012, 7, e47709. [CrossRef] [PubMed]

139. Volinia, S.; Galasso, M.; Sana, M.E.; Wise, T.F.; Palatini, J.; Huebner, K.; Croce, C.M. Breast cancer signatures for invasiveness and prognosis defined by deep sequencing of microRNA. Proc. Natl. Acad. Sci. USA 2012, 109, 3024-3029. [CrossRef] [PubMed]

140. Dykxhoorn, D.M.; Wu, Y.; Xie, H.; Yu, F.; Lal, A.; Petrocca, F.; Martinvalet, D.; Song, E.; Lim, B.; Lieberman, J. miR-200 enhances mouse breast cancer cell colonization to form distant metastases. PLoS ONE 2009, 4, e7181. [CrossRef] [PubMed]

141. Korpal, M.; Ell, B.J.; Buffa, F.M.; Ibrahim, T.; Blanco, M.A.; Celia-Terrassa, T.; Mercatali, L.; Khan, Z.; Goodarzi, H.; Hua, Y.; et al. Direct targeting of Sec23a by miR-200s influences cancer cell secretome and promotes metastatic colonization. Nat. Med. 2011, 17, 1101-1108. [CrossRef] [PubMed]

142. Gregory, P.A.; Bracken, C.P.; Smith, E.; Bert, A.G.; Wright, J.A.; Roslan, S.; Morris, M.; Wyatt, L.; Farshid, G.; Lim, Y.Y.; et al. An autocrine TGF- $\beta / Z E B / m i R-200$ signaling network regulates establishment and maintenance of epithelial-mesenchymal transition. Mol. Biol. Cell 2011, 22, 1686-1698. [CrossRef] [PubMed]

143. Howe, E.N.; Cochrane, D.R.; Cittelly, D.M.; Richer, J.K. MiR-200c targets a NF- $\mathrm{kB}$ up-regulated Trkb/NTF3 autocrine signaling loop to enhance anoikis sensitivity in triple negative breast cancer. PLoS ONE 2012, 7, e49987. [CrossRef] [PubMed]

144. Baulida, J.; Garcia de Herreros, A. Snail1-driven plasticity of epithelial and mesenchymal cells sustains cancer malignancy. Biochim. Biophys. Acta 2015, 1856, 55-61. [CrossRef] [PubMed]

145. Fang, J.H.; Zhou, H.C.; Zhang, C.; Shang, L.R.; Zhang, L.; Xu, J.; Zheng, L.; Yuan, Y.; Guo, R.P.; Jia, W.H.; et al . A novel vascular pattern promotes metastasis of hepatocellular carcinoma in an epithelial-mesenchymal transition-independent manner. Hepatology 2015, 62, 452-465. [CrossRef] [PubMed]

146. Gao, J.; Zhu, Y.; Nilsson, M.; Sundfeldt, K. TGF- $\beta$ isoforms induce emt independent migration of ovarian cancer cells. Cancer Cell Int. 2014, 14. [CrossRef] [PubMed]

147. Zhang, P.; Sun, Y.; Ma, L. ZEB1: At the crossroads of epithelial-mesenchymal transition, metastasis and therapy resistance. Cell Cycle 2015, 14, 481-487. [CrossRef] [PubMed]

148. Han, M.; Wang, Y.; Liu, M.; Bi, X.; Bao, J.; Zeng, N.; Zhu, Z.; Mo, Z.; Wu, C.; Chen, X. MiR-21 regulates epithelial-mesenchymal transition phenotype and hypoxia-inducible factor- $1 \alpha$ expression in third-sphere forming breast cancer stem cell-like cells. Cancer Sci. 2012, 103, 1058-1064. [CrossRef] [PubMed]

149. Huang, T.H.; Wu, F.; Loeb, G.B.; Hsu, R.; Heidersbach, A.; Brincat, A.; Horiuchi, D.; Lebbink, R.J.; Mo, Y.Y.; Goga, A.; et al. Up-regulation of miR-21 by HER2/neu signaling promotes cell invasion. J. Biol.Chem. 2009, 284, 18515-18524. [CrossRef] [PubMed]

150. Yan, L.X.; Huang, X.F.; Shao, Q.; Huang, M.Y.; Deng, L.; Wu, Q.L.; Zeng, Y.X.; Shao, J.Y. MicroRNA miR-21 overexpression in human breast cancer is associated with advanced clinical stage, lymph node metastasis and patient poor prognosis. RNA 2008, 14, 2348-2360. [CrossRef] [PubMed] 
151. Jiang, H.; Zhang, G.; Wu, J.H.; Jiang, C.P. Diverse roles of miR-29 in cancer (review). Oncol. Rep. 2014, 31, 1509-1516. [CrossRef] [PubMed]

152. Rostas, J.W., 3rd; Pruitt, H.C.; Metge, B.J.; Mitra, A.; Bailey, S.K.; Bae, S.; Singh, K.P.; Devine, D.J.; Dyess, D.L.; Richards, W.O.; et al. MicroRNA-29 negatively regulates EMT regulator N-myc interactor in breast cancer. Mol. Cancer 2014, 13. [CrossRef] [PubMed]

153. Han, X.; Yan, S.; Weijie, Z.; Feng, W.; Liuxing, W.; Mengquan, L.; Qingxia, F. Critical role of miR-10b in transforming growth factor- $\beta 1$-induced epithelial-mesenchymal transition in breast cancer. Cancer Gene Ther. 2014, 21, 60-67. [CrossRef] [PubMed]

154. Minard, M.E.; Ellis, L.M.; Gallick, G.E. Tiam1 regulates cell adhesion, migration and apoptosis in colon tumor cells. Clin. Exp. Metastasis 2006, 23, 301-313. [CrossRef] [PubMed]

155. Gwak, J.M.; Kim, H.J.; Kim, E.J.; Chung, Y.R.; Yun, S.; Seo, A.N.; Lee, H.J.; Park, S.Y. MicroRNA-9 is associated with epithelial-mesenchymal transition, breast cancer stem cell phenotype, and tumor progression in breast cancer. Breast Cancer Res. Treat. 2014, 147, 39-49. [CrossRef] [PubMed]

156. Ma, L.; Young, J.; Prabhala, H.; Pan, E.; Mestdagh, P.; Muth, D.; Teruya-Feldstein, J.; Reinhardt, F.; Onder, T.T.; Valastyan, S.; et al. miR-9, a MYC/MYCN-activated microRNA, regulates E-cadherin and cancer metastasis. Nat. Cell Biol. 2010, 12, 247-256. [CrossRef] [PubMed]

157. Adams, B.D.; Furneaux, H.; White, B.A. The micro-ribonucleic acid (miRNA) miR-206 targets the human estrogen receptor- $\alpha(E R \alpha)$ and represses $E R \alpha$ messenger RNA and protein expression in breast cancer cell lines. Mol. Endocrinol. 2007, 21, 1132-1147. [CrossRef] [PubMed]

158. Iorio, M.V.; Ferracin, M.; Liu, C.G.; Veronese, A.; Spizzo, R.; Sabbioni, S.; Magri, E.; Pedriali, M.; Fabbri, M.; Campiglio, M.; et al. MicroRNA gene expression deregulation in human breast cancer. Cancer Res. 2005, 65, 7065-7070. [CrossRef] [PubMed]

159. Kondo, N.; Toyama, T.; Sugiura, H.; Fujii, Y.; Yamashita, H. miR-206 expression is down-regulated in estrogen receptor $\alpha$-positive human breast cancer. Cancer Res. 2008, 68, 5004-5008. [CrossRef] [PubMed]

160. Guttilla, I.K.; Phoenix, K.N.; Hong, X.; Tirnauer, J.S.; Claffey, K.P.; White, B.A. Prolonged mammosphere culture of MCF-7 cells induces an emt and repression of the estrogen receptor by microRNAs. Breast Cancer Res. Treat. 2012, 132, 75-85. [CrossRef] [PubMed]

161. Zhao, J.J.; Lin, J.; Yang, H.; Kong, W.; He, L.; Ma, X.; Coppola, D.; Cheng, J.Q. MicroRNA-221/222 negatively regulates estrogen receptor $\alpha$ and is associated with tamoxifen resistance in breast cancer. J. Biol. Chem. 2008, 283, 31079-31086. [CrossRef] [PubMed]

162. Cao, M.; Nie, W.; Li, J.; Zhang, Y.; Yan, X.; Guan, X.; Chen, X.; Zen, K.; Zhang, C.Y.; Jiang, X.; et al. MicroRNA-495 induces breast cancer cell migration by targeting JAM-A. Protein Cell 2014, 5, 862-872. [CrossRef] [PubMed]

163. Hwang-Verslues, W.W.; Chang, P.H.; Wei, P.C.; Yang, C.Y.; Huang, C.K.; Kuo, W.H.; Shew, J.Y.; Chang, K.J.; Lee, E.Y.; Lee, W.H. MiR-495 is upregulated by E12/E47 in breast cancer stem cells, and promotes oncogenesis and hypoxia resistance via downregulation of E-cadherin and redd1. Oncogene 2011, 30, 2463-2474. [CrossRef] [PubMed]

164. Neel, J.C.; Lebrun, J.J. Activin and TGF $\beta$ regulate expression of the microRNA-181 family to promote cell migration and invasion in breast cancer cells. Cell Signal. 2013, 25, 1556-1566. [CrossRef] [PubMed]

165. Castellano, L.; Giamas, G.; Jacob, J.; Coombes, R.C.; Lucchesi, W.; Thiruchelvam, P.; Barton, G.; Jiao, L.R.; Wait, R.; Waxman, J.; et al. The estrogen receptor- $\alpha$-induced microRNA signature regulates itself and its transcriptional response. Proc. Natl. Acad. Sci. USA 2009, 106, 15732-15737. [CrossRef] [PubMed]

166. Yu, Z.; Wang, C.; Wang, M.; Li, Z.; Casimiro, M.C.; Liu, M.; Wu, K.; Whittle, J.; Ju, X.; Hyslop, T.; et al. A cyclin D1/microRNA 17/20 regulatory feedback loop in control of breast cancer cell proliferation. J. Cell Biol. 2008, 182, 509-517. [CrossRef] [PubMed]

167. Acunzo, M.; Visone, R.; Romano, G.; Veronese, A.; Lovat, F.; Palmieri, D.; Bottoni, A.; Garofalo, M.; Gasparini, P.; Condorelli, G.; et al. miR-130a targets met and induces trail-sensitivity in NSCLC by downregulating miR-221 and 222. Oncogene 2012, 31, 634-642. [CrossRef] [PubMed]

168. Gotte, M.; Mohr, C.; Koo, C.Y.; Stock, C.; Vaske, A.K.; Viola, M.; Ibrahim, S.A.; Peddibhotla, S.; Teng, Y.H.; Low, J.Y.; et al. miR-145-dependent targeting of junctional adhesion molecule A and modulation of fascin expression are associated with reduced breast cancer cell motility and invasiveness. Oncogene 2010, 29, 6569-6580. [CrossRef] [PubMed]

169. Sachdeva, M.; Mo, Y.Y. MicroRNA-145 suppresses cell invasion and metastasis by directly targeting mucin 1. Cancer Res. 2010, 70, 378-387. [CrossRef] [PubMed] 
170. Spizzo, R.; Nicoloso, M.S.; Lupini, L.; Lu, Y.; Fogarty, J.; Rossi, S.; Zagatti, B.; Fabbri, M.; Veronese, A.; Liu, X.; et al. miR-145 participates with TP53 in a death-promoting regulatory loop and targets estrogen receptor- $\alpha$ in human breast cancer cells. Cell Death Differ. 2010, 17, 246-254. [CrossRef] [PubMed]

171. Zhang, H.; Cai, K.; Wang, J.; Wang, X.; Cheng, K.; Shi, F.; Jiang, L.; Zhang, Y.; Dou, J. MiR-7, inhibited indirectly by lincrna hotair, directly inhibits SETDB1 and reverses the emt of breast cancer stem cells by downregulating the STAT3 pathway. Stem Cells 2014, 32, 2858-2868. [CrossRef] [PubMed]

172. Hong, S.; Noh, H.; Teng, Y.; Shao, J.; Rehmani, H.; Ding, H.F.; Dong, Z.; Su, S.B.; Shi, H.; Kim, J.; et al. SHOX2 is a direct miR-375 target and a novel epithelial-to-mesenchymal transition inducer in breast cancer cells. Neoplasia 2014, 16, 279-290. [CrossRef] [PubMed]

173. Parker, J.S.; Mullins, M.; Cheang, M.C.U.; Leung, S.; Voduc, D.; Vickery, T.; Davies, S.; Fauron, C.; He, X.; $\mathrm{Hu}, \mathrm{Z}$; ; et al. Supervised risk predictor of breast cancer based on intrinsic subtypes. J. Clin. Oncol. 2009, 27, 1160-1167. [CrossRef] [PubMed]

174. Cortez, M.A.; Welsh, J.W.; Calin, G.A. Circulating microRNAs as noninvasive biomarkers in breast cancer. Recent Results Cancer Res. 2012, 195, 151-161. [PubMed]

175. Roth, C.; Rack, B.; Muller, V.; Janni, W.; Pantel, K.; Schwarzenbach, H. Circulating microRNAs as blood-based markers for patients with primary and metastatic breast cancer. Breast Cancer Res. BCR 2010, 12. [CrossRef] [PubMed]

176. Sochor, M.; Basova, P.; Pesta, M.; Dusilkova, N.; Bartos, J.; Burda, P.; Pospisil, V.; Stopka, T. Oncogenic microRNAs: miR-155, miR-19a, miR-181b, and miR-24 enable monitoring of early breast cancer in serum. BMC Cancer 2014, 14. [CrossRef] [PubMed]

177. Wang, F.; Zheng, Z.; Guo, J.; Ding, X. Correlation and quantitation of microRNA aberrant expression in tissues and sera from patients with breast tumor. Gynecol. Oncol. 2010, 119, 586-593. [CrossRef] [PubMed]

178. Eichelser, C.; Flesch-Janys, D.; Chang-Claude, J.; Pantel, K.; Schwarzenbach, H. Deregulated serum concentrations of circulating cell-free microRNAs miR-17, miR-34a, miR-155, and miR-373 in human breast cancer development and progression. Clin. Chem. 2013, 59, 1489-1496. [CrossRef] [PubMed]

179. Wang, F.; Hou, J.; Jin, W.; Li, J.; Yue, Y.; Jin, H.; Wang, X. Increased circulating microRNA-155 as a potential biomarker for breast cancer screening: A meta-analysis. Molecules 2014, 19, 6282-6293. [CrossRef] [PubMed]

180. Dinami, R.; Ercolani, C.; Petti, E.; Piazza, S.; Ciani, Y.; Sestito, R.; Sacconi, A.; Biagioni, F.; le Sage, C.; Agami, R.; et al. miR-155 drives telomere fragility in human breast cancer by targeting TRF1. Cancer Res. 2014, 74, 4145-4156. [CrossRef] [PubMed]

181. Asaga, S.; Kuo, C.; Nguyen, T.; Terpenning, M.; Giuliano, A.E.; Hoon, D.S. Direct serum assay for microRNA-21 concentrations in early and advanced breast cancer. Clin. Chem. 2011, 57, 84-91. [CrossRef] [PubMed]

182. Schwarzenbach, H.; Milde-Langosch, K.; Steinbach, B.; Muller, V.; Pantel, K. Diagnostic potential of PTEN-targeting miR-214 in the blood of breast cancer patients. Breast Cancer Res. Treat. 2012, 134, 933-941. [CrossRef] [PubMed]

183. Wu, Q.; Lu, Z.; Li, H.; Lu, J.; Guo, L.; Ge, Q. Next-generation sequencing of microRNAs for breast cancer detection. J. Biomed. Biotechnol. 2011, 2011. [CrossRef] [PubMed]

184. Van Schooneveld, E.; Wouters, M.C.; van der Auwera, I.; Peeters, D.J.; Wildiers, H.; van Dam, P.A.; Vergote, I.; Vermeulen, P.B.; Dirix, L.Y.; van Laere, S.J. Expression profiling of cancerous and normal breast tissues identifies microRNAs that are differentially expressed in serum from patients with (metastatic) breast cancer and healthy volunteers. Breast Cancer Res. BCR 2012, 14. [CrossRef] [PubMed]

185. Zhao, H.; Shen, J.; Medico, L.; Wang, D.; Ambrosone, C.B.; Liu, S. A pilot study of circulating miRNAs as potential biomarkers of early stage breast cancer. PLoS ONE 2010, 5, e13735. [CrossRef] [PubMed]

186. Eichelser, C.; Stuckrath, I.; Muller, V.; Milde-Langosch, K.; Wikman, H.; Pantel, K.; Schwarzenbach, H. Increased serum levels of circulating exosomal microRNA-373 in receptor-negative breast cancer patients. Oncotarget 2014, 5, 9650-9663. [CrossRef] [PubMed]

187. Jung, E.J.; Santarpia, L.; Kim, J.; Esteva, F.J.; Moretti, E.; Buzdar, A.U.; di Leo, A.; Le, X.F.; Bast, R.C., Jr.; Park, S.T.; et al. Plasma microRNA 210 levels correlate with sensitivity to trastuzumab and tumor presence in breast cancer patients. Cancer 2012, 118, 2603-2614. [CrossRef] [PubMed]

188. Kleivi-Sahlberg, K.; Bottai, G.; Naume, B.; Burwinkel, B.; Calin, G.A.; Borresen-Dale, A.L.; Santarpia, L. A serum microRNA signature predicts tumor relapse and survival in triple-negative breast cancer patients. Clin. Cancer Res. 2015, 21, 1207-1214. [CrossRef] [PubMed] 
189. Zhao, F.L.; Hu, G.D.; Wang, X.F.; Zhang, X.H.; Zhang, Y.K.; Yu, Z.S. Serum overexpression of microRNA-10b in patients with bone metastatic primary breast cancer. J. Int. Med. Res. 2012, 40, 859-866. [CrossRef] [PubMed]

190. Madhavan, D.; Zucknick, M.; Wallwiener, M.; Cuk, K.; Modugno, C.; Scharpff, M.; Schott, S.; Heil, J.; Turchinovich, A.; Yang, R.; et al. Circulating mirnas as surrogate markers for circulating tumor cells and prognostic markers in metastatic breast cancer. Clin. Cancer Res. 2012, 18, 5972-5982. [CrossRef] [PubMed]

191. Shin, V.Y.; Siu, J.M.; Cheuk, I.; Ng, E.K.; Kwong, A. Circulating cell-free mirnas as biomarker for triple-negative breast cancer. Br. J. Cancer 2015, 112, 1751-1759. [CrossRef] [PubMed]

192. Lim, P.K.; Bliss, S.A.; Patel, S.A.; Taborga, M.; Dave, M.A.; Gregory, L.A.; Greco, S.J.; Bryan, M.; Patel, P.S.; Rameshwar, P. Gap junction-mediated import of microRNA from bone marrow stromal cells can elicit cell cycle quiescence in breast cancer cells. Cancer Res. 2011, 71, 1550-1560. [CrossRef] [PubMed]

193. Yang, M.; Chen, J.; Su, F.; Yu, B.; Lin, L.; Liu, Y.; Huang, J.D.; Song, E. Microvesicles secreted by macrophages shuttle invasion-potentiating microRNAs into breast cancer cells. Mol. Cancer 2011, 10. [CrossRef] [PubMed]

194. Chen, W.X.; Liu, X.M.; Lv, M.M.; Chen, L.; Zhao, J.H.; Zhong, S.L.; Ji, M.H.; Hu, Q.; Luo, Z.; Wu, J.Z.; et al. Exosomes from drug-resistant breast cancer cells transmit chemoresistance by a horizontal transfer of microRNAs. PLoS ONE 2014, 9, e95240. [CrossRef] [PubMed]

195. Zhou, W.; Fong, M.Y.; Min, Y.; Somlo, G.; Liu, L.; Palomares, M.R.; Yu, Y.; Chow, A.; O'Connor, S.T.; Chin, A.R.; et al. Cancer-secreted miR-105 destroys vascular endothelial barriers to promote metastasis. Cancer Cell 2014, 25, 501-515. [CrossRef] [PubMed]

196. Pecot, C.V.; Calin, G.A.; Coleman, R.L.; Lopez-Berestein, G.; Sood, A.K. RNA interference in the clinic: Challenges and future directions. Nat. Rev. Cancer 2011, 11, 59-67. [CrossRef] [PubMed]

197. Song, E.; Lee, S.K.; Wang, J.; Ince, N.; Ouyang, N.; Min, J.; Chen, J.; Shankar, P.; Lieberman, J. RNA interference targeting fas protects mice from fulminant hepatitis. Nat. Med. 2003, 9, 347-351. [CrossRef] [PubMed]

198. Krutzfeldt, J.; Rajewsky, N.; Braich, R.; Rajeev, K.G.; Tuschl, T.; Manoharan, M.; Stoffel, M. Silencing of microRNAs in vivo with "antagomirs". Nature 2005, 438, 685-689. [CrossRef] [PubMed]

199. Nana-Sinkam, S.P.; Croce, C.M. MicroRNAs as therapeutic targets in cancer. Transl. Res. Lab. Clin. Med. 2011, 157, 216-225. [CrossRef] [PubMed]

200. Xing, Z.; Lin, A.; Li, C.; Liang, K.; Wang, S.; Liu, Y.; Park, P.K.; Qin, L.; Wei, Y.; Hawke, D.H.; et al. LncRNA directs cooperative epigenetic regulation downstream of chemokine signals. Cell 2014, 159, 1110-1125. [CrossRef] [PubMed]

201. Ebert, M.S.; Neilson, J.R.; Sharp, P.A. MicroRNA sponges: Competitive inhibitors of small RNAs in mammalian cells. Nat. Methods 2007, 4, 721-726. [CrossRef] [PubMed]

202. Petrs-Silva, H.; Linden, R. Advances in recombinant adeno-associated viral vectors for gene delivery. Curr. Gene Ther. 2013, 13, 335-345. [CrossRef] [PubMed]

203. Kota, J.; Chivukula, R.R.; O’Donnell, K.A.; Wentzel, E.A.; Montgomery, C.L.; Hwang, H.W.; Chang, T.C.; Vivekanandan, P.; Torbenson, M.; Clark, K.R.; et al. Therapeutic microRNA delivery suppresses tumorigenesis in a murine liver cancer model. Cell 2009, 137, 1005-1017. [CrossRef] [PubMed]

204. Trepel, M.; Korbelin, J.; Spies, E.; Heckmann, M.B.; Hunger, A.; Fehse, B.; Katus, H.A.; Kleinschmidt, J.A.; Muller, O.J.; Michelfelder, S. Treatment of multifocal breast cancer by systemic delivery of dual-targeted adeno-associated viral vectors. Gene Ther. 2015, 22, 840-847. [CrossRef] [PubMed]

205. Gandellini, P.; Profumo, V.; Folini, M.; Zaffaroni, N. MicroRNAs as new therapeutic targets and tools in cancer. Expert Opin. Ther. Targets 2011, 15, 265-279. [CrossRef] [PubMed]

206. Muthiah, M.; Park, I.K.; Cho, C.S. Nanoparticle-mediated delivery of therapeutic genes: Focus on miRNA therapeutics. Expert Opin. Drug Deliv. 2013, 10, 1259-1273. [CrossRef] [PubMed]

207. Shu, D.; Li, H.; Shu, Y.; Xiong, G.; Carson, W.E., 3rd; Haque, F.; Xu, R.; Guo, P. Systemic delivery of anti-miRNA for suppression of triple negative breast cancer utilizing RNA nanotechnology. ACS Nano 2015, 9, 9731-9740. [CrossRef] [PubMed]

208. Portela, A.; Esteller, M. Epigenetic modifications and human disease. Nat. Biotechnol. 2010, 28, 1057-1068. [CrossRef] [PubMed]

209. Fraga, M.F.; Ballestar, E.; Paz, M.F.; Ropero, S.; Setien, F.; Ballestar, M.L.; Heine-Suner, D.; Cigudosa, J.C.; Urioste, M.; Benitez, J.; et al. Epigenetic differences arise during the lifetime of monozygotic twins. Proc. Natl. Acad. Sci. USA 2005, 102, 10604-10609. [CrossRef] [PubMed] 
210. Kaminsky, Z.A.; Tang, T.; Wang, S.C.; Ptak, C.; Oh, G.H.; Wong, A.H.; Feldcamp, L.A.; Virtanen, C.; Halfvarson, J.; Tysk, C.; et al. DNA methylation profiles in monozygotic and dizygotic twins. Nat. Genet. 2009, 41, 240-245. [CrossRef] [PubMed]

211. Feinberg, A.P.; Vogelstein, B. Hypomethylation distinguishes genes of some human cancers from their normal counterparts. Nature 1983, 301, 89-92. [CrossRef] [PubMed]

212. Altun, G.; Loring, J.F.; Laurent, L.C. DNA methylation in embryonic stem cells. J. Cell. Biochem. 2010, 109, 1-6. [CrossRef] [PubMed]

213. Straussman, R.; Nejman, D.; Roberts, D.; Steinfeld, I.; Blum, B.; Benvenisty, N.; Simon, I.; Yakhini, Z.; Cedar, H. Developmental programming of $\mathrm{CpG}$ island methylation profiles in the human genome. Nat. Struct. Mol. Biol. 2009, 16, 564-571. [CrossRef] [PubMed]

214. Li, E.; Bestor, T.H.; Jaenisch, R. Targeted mutation of the DNA methyltransferase gene results in embryonic lethality. Cell 1992, 69, 915-926. [CrossRef]

215. Okano, M.; Bell, D.W.; Haber, D.A.; Li, E. DNA methyltransferases DNMT3A and DNMT3B are essential for de novo methylation and mammalian development. Cell 1999, 99, 247-257. [CrossRef]

216. Lopez-Serra, L.; Esteller, M. Proteins that bind methylated DNA and human cancer: Reading the wrong words. Br. J. Cancer 2008, 98, 1881-1885. [CrossRef] [PubMed]

217. Medvedeva, Y.A.; Khamis, A.M.; Kulakovskiy, I.V.; Ba-Alawi, W.; Bhuyan, M.S.; Kawaji, H.; Lassmann, T.; Harbers, M.; Forrest, A.R.; Bajic, V.B. Effects of cytosine methylation on transcription factor binding sites. BMC Genom. 2014, 15. [CrossRef] [PubMed]

218. Watt, F.; Molloy, P.L. Cytosine methylation prevents binding to DNA of a hela cell transcription factor required for optimal expression of the adenovirus major late promoter. Genes Dev. 1988, 2, 1136-1143. [CrossRef] [PubMed]

219. Doi, A.; Park, I.-H.; Wen, B.; Murakami, P.; Aryee, M.J.; Irizarry, R.; Herb, B.; Ladd-Acosta, C.; Rho, J.; Loewer, S.; et al. Differential methylation of tissue- and cancer-specific cpg island shores distinguishes human induced pluripotent stem cells, embryonic stem cells and fibroblasts. Nat. Genet. 2009, 41, 1350-1353. [CrossRef] [PubMed]

220. Urdinguio, R.G.; Sanchez-Mut, J.V.; Esteller, M. Epigenetic mechanisms in neurological diseases: Genes, syndromes, and therapies. Lancet Neurol. 2009, 8, 1056-1072. [CrossRef]

221. Berman, H.; Zhang, J.; Crawford, Y.G.; Gauthier, M.L.; Fordyce, C.A.; McDermott, K.M.; Sigaroudinia, M.; Kozakiewicz, K.; Tlsty, T.D. Genetic and epigenetic changes in mammary epithelial cells identify a subpopulation of cells involved in early carcinogenesis. Cold Spring Harb. Symp. Quant. Biol. 2005, 70, 317-327. [CrossRef] [PubMed]

222. Dickinson, R.E.; Dallol, A.; Bieche, I.; Krex, D.; Morton, D.; Maher, E.R.; Latif, F. Epigenetic inactivation of SLIT3 and SLIT1 genes in human cancers. Br. J. Cancer 2004, 91, 2071-2078. [CrossRef] [PubMed]

223. Yan, P.S.; Perry, M.R.; Laux, D.E.; Asare, A.L.; Caldwell, C.W.; Huang, T.H. CpG island arrays: An application toward deciphering epigenetic signatures of breast cancer. Clin. Cancer Res. 2000, 6, 1432-1438. [PubMed]

224. Widschwendter, M.; Siegmund, K.D.; Muller, H.M.; Fiegl, H.; Marth, C.; Muller-Holzner, E.; Jones, P.A.; Laird, P.W. Association of breast cancer DNA methylation profiles with hormone receptor status and response to tamoxifen. Cancer Res. 2004, 64, 3807-3813. [CrossRef] [PubMed]

225. Keshet, I.; Schlesinger, Y.; Farkash, S.; Rand, E.; Hecht, M.; Segal, E.; Pikarski, E.; Young, R.A.; Niveleau, A.; Cedar, H.; et al. Evidence for an instructive mechanism of de novo methylation in cancer cells. Nat. Genet. 2006, 38, 149-153. [CrossRef] [PubMed]

226. Ruike, Y.; Imanaka, Y.; Sato, F.; Shimizu, K.; Tsujimoto, G. Genome-wide analysis of aberrant methylation in human breast cancer cells using methyl-DNA immunoprecipitation combined with high-throughput sequencing. BMC Genom. 2010, 11. [CrossRef] [PubMed]

227. Lister, R.; Pelizzola, M.; Dowen, R.H.; Hawkins, R.D.; Hon, G.; Tonti-Filippini, J.; Nery, J.R.; Lee, L.; Ye, Z.; Ngo, Q.M.; et al. Human DNA methylomes at base resolution show widespread epigenomic differences. Nature 2009, 462, 315-322. [CrossRef] [PubMed]

228. Bibikova, M.; Barnes, B.; Tsan, C.; Ho, V.; Klotzle, B.; Le, J.M.; Delano, D.; Zhang, L.; Schroth, G.P.; Gunderson, K.L.; et al. High density DNA methylation array with single CpG site resolution. Genomics 2011, 98, 288-295. [CrossRef] [PubMed]

229. Pang, J.M.; Dobrovic, A.; Fox, S.B. DNA methylation in ductal carcinoma in situ of the breast. Breast Cancer Res. BCR 2013, 15. [CrossRef] [PubMed] 
230. Muggerud, A.A.; Ronneberg, J.A.; Warnberg, F.; Botling, J.; Busato, F.; Jovanovic, J.; Solvang, H.; Bukholm, I.; Borresen-Dale, A.L.; Kristensen, V.N.; et al. Frequent aberrant DNA methylation of ABCB1, FOXC1, PPP2R2B and PTEN in ductal carcinoma in situ and early invasive breast cancer. Breast Cancer Res. BCR 2010, 12. [CrossRef] [PubMed]

231. Van Hoesel, A.Q.; Sato, Y.; Elashoff, D.A.; Turner, R.R.; Giuliano, A.E.; Shamonki, J.M.; Kuppen, P.J.; van de Velde, C.J.; Hoon, D.S. Assessment of DNA methylation status in early stages of breast cancer development. Br. J. Cancer 2013, 108, 2033-2038. [CrossRef] [PubMed]

232. Fleischer, T.; Frigessi, A.; Johnson, K.C.; Edvardsen, H.; Touleimat, N.; Klajic, J.; Riis, M.L.; Haakensen, V.D.; Warnberg, F.; Naume, B.; et al. Genome-wide DNA methylation profiles in progression to in situ and invasive carcinoma of the breast with impact on gene transcription and prognosis. Genome Biol. 2014, 15. [CrossRef]

233. Bediaga, N.G.; Acha-Sagredo, A.; Guerra, I.; Viguri, A.; Albaina, C.; Ruiz Diaz, I.; Rezola, R.; Alberdi, M.J.; Dopazo, J.; Montaner, D.; et al. DNA methylation epigenotypes in breast cancer molecular subtypes. Breast Cancer Res. BCR 2010, 12. [CrossRef] [PubMed]

234. Holm, K.; Hegardt, C.; Staaf, J.; Vallon-Christersson, J.; Jonsson, G.; Olsson, H.; Borg, A.; Ringner, M. Molecular subtypes of breast cancer are associated with characteristic DNA methylation patterns. Breast Cancer Res. BCR 2010, 12. [CrossRef] [PubMed]

235. Ronneberg, J.A.; Fleischer, T.; Solvang, H.K.; Nordgard, S.H.; Edvardsen, H.; Potapenko, I.; Nebdal, D.; Daviaud, C.; Gut, I.; Bukholm, I.; et al. Methylation profiling with a panel of cancer related genes: Association with estrogen receptor, TP53 mutation status and expression subtypes in sporadic breast cancer. Mol. Oncol. 2011, 5, 61-76. [CrossRef] [PubMed]

236. Flanagan, J.M.; Cocciardi, S.; Waddell, N.; Johnstone, C.N.; Marsh, A.; Henderson, S.; Simpson, P.; da Silva, L.; Khanna, K.; Lakhani, S.; et al. DNA methylome of familial breast cancer identifies distinct profiles defined by mutation status. Am. J. Hum. Genet. 2010, 86, 420-433. [CrossRef] [PubMed]

237. Conway, K.; Edmiston, S.N.; May, R.; Kuan, P.F.; Chu, H.; Bryant, C.; Tse, C.K.; Swift-Scanlan, T.; Geradts, J.; Troester, M.A.; et al. DNA methylation profiling in the carolina breast cancer study defines cancer subclasses differing in clinicopathologic characteristics and survival. Breast Cancer Res. BCR 2014, 16. [CrossRef] [PubMed]

238. Stefansson, O.A.; Moran, S.; Gomez, A.; Sayols, S.; Arribas-Jorba, C.; Sandoval, J.; Hilmarsdottir, H.; Olafsdottir, E.; Tryggvadottir, L.; Jonasson, J.G.; et al. A DNA methylation-based definition of biologically distinct breast cancer subtypes. Mol. Oncol. 2015, 9, 555-568. [CrossRef] [PubMed]

239. Jing, F.; Yuping, W.; Yong, C.; Jie, L.; Jun, L.; Xuanbing, T.; Lihua, H. CpG island methylator phenotype of multigene in serum of sporadic breast carcinoma. Tumour Biol. 2010, 31, 321-331. [CrossRef] [PubMed]

240. Radpour, R.; Barekati, Z.; Kohler, C.; Lv, Q.; Burki, N.; Diesch, C.; Bitzer, J.; Zheng, H.; Schmid, S.; Zhong, X.Y. Hypermethylation of tumor suppressor genes involved in critical regulatory pathways for developing a blood-based test in breast cancer. PLoS ONE 2011, 6, e16080. [CrossRef] [PubMed]

241. Stirzaker, C.; Zotenko, E.; Song, J.Z.; Qu, W.; Nair, S.S.; Locke, W.J.; Stone, A.; Armstong, N.J.; Robinson, M.D.; Dobrovic, A.; et al. Methylome sequencing in triple-negative breast cancer reveals distinct methylation clusters with prognostic value. Nat. Commun. 2015, 6. [CrossRef] [PubMed]

242. Veeck, J.; Ropero, S.; Setien, F.; Gonzalez-Suarez, E.; Osorio, A.; Benitez, J.; Herman, J.G.; Esteller, M. BRCA1 CpG island hypermethylation predicts sensitivity to poly(adenosine diphosphate)-ribose polymerase inhibitors. J. Clin. Oncol. 2010, 28, e563-e564. [CrossRef] [PubMed]

243. Stefansson, O.A.; Jonasson, J.G.; Olafsdottir, K.; Hilmarsdottir, H.; Olafsdottir, G.; Esteller, M.; Johannsson, O.T.; Eyfjord, J.E. CpG island hypermethylation of BRCA1 and loss of PRB as co-occurring events in basal/triple-negative breast cancer. Epigenetics 2011, 6, 638-649. [CrossRef] [PubMed]

244. Watanabe, Y.; Maeda, I.; Oikawa, R.; Wu, W.; Tsuchiya, K.; Miyoshi, Y.; Itoh, F.; Tsugawa, K.; Ohta, T. Aberrant DNA methylation status of DNA repair genes in breast cancer treated with neoadjuvant chemotherapy. Genes Cells 2013, 18, 1120-1130. [CrossRef] [PubMed]

245. Sharma, P.; Stecklein, S.R.; Kimler, B.F.; Sethi, G.; Petroff, B.K.; Phillips, T.A.; Tawfik, O.W.; Godwin, A.K.; Jensen, R.A. The prognostic value of promoter methylation in early stage triple negative breast cancer. J. Cancer Ther. Res. 2014, 3, 1-11. [CrossRef] [PubMed]

246. Xu, Y.; Diao, L.; Chen, Y.; Liu, Y.; Wang, C.; Ouyang, T.; Li, J.; Wang, T.; Fan, Z.; Fan, T.; et al. Promoter methylation of BRCA1 in triple-negative breast cancer predicts sensitivity to adjuvant chemotherapy. Ann. Oncol. 2013, 24, 1498-1505. [CrossRef] [PubMed] 
247. Ignatov, T.; Poehlmann, A.; Ignatov, A.; Schinlauer, A.; Costa, S.D.; Roessner, A.; Kalinski, T.; Bischoff, J. BRCA1 promoter methylation is a marker of better response to anthracycline-based therapy in sporadic tnbc. Breast Cancer Res. Treat. 2013, 141, 205-212. [CrossRef] [PubMed]

248. Duursma, A.M.; Kedde, M.; Schrier, M.; le Sage, C.; Agami, R. miR-148 targets human DNMT3b protein coding region. RNA 2008, 14, 872-877. [CrossRef] [PubMed]

249. Fabbri, M.; Garzon, R.; Cimmino, A.; Liu, Z.; Zanesi, N.; Callegari, E.; Liu, S.; Alder, H.; Costinean, S.; Fernandez-Cymering, C.; et al. MicroRNA-29 family reverts aberrant methylation in lung cancer by targeting DNA methyltransferases 3a and 3b. Proc. Natl. Acad. Sci. USA 2007, 104, 15805-15810. [CrossRef] [PubMed]

250. Rodriguez, A.; Griffiths-Jones, S.; Ashurst, J.L.; Bradley, A. Identification of mammalian microRNA host genes and transcription units. Genome Res. 2004, 14, 1902-1910. [CrossRef] [PubMed]

251. Ying, S.Y.; Lin, S.L. Intronic microRNAs. Biochem. Biophys. Res. Commun. 2005, 326, 515-520. [CrossRef] [PubMed]

252. Wee, E.J.H.; Peters, K.; Nair, S.S.; Hulf, T.; Stein, S.; Wagner, S.; Bailey, P.; Lee, S.Y.; Qu, W.J.; Brewster, B.; et al. Mapping the regulatory sequences controlling 93 breast cancer-associated miRNA genes leads to the identification of two functional promoters of the hsa-miR-200b cluster, methylation of which is associated with metastasis or hormone receptor status in advanced breast cancer. Oncogene 2012, 31, 4182-4195. [PubMed]

253. Lehmann, U.; Hasemeier, B.; Christgen, M.; Muller, M.; Romermann, D.; Langer, F.; Kreipe, H. Epigenetic inactivation of microRNA gene hsa-miR-9-1 in human breast cancer. J. Pathol. 2008, 214, 17-24. [CrossRef] [PubMed]

254. Lujambio, A.; Calin, G.A.; Villanueva, A.; Ropero, S.; Sanchez-Cespedes, M.; Blanco, D.; Montuenga, L.M.; Rossi, S.; Nicoloso, M.S.; Faller, W.J.; et al. A microRNA DNA methylation signature for human cancer metastasis. Proc. Natl. Acad. Sci. USA 2008, 105, 13556-13561. [CrossRef] [PubMed]

255. Lujambio, A.; Ropero, S.; Ballestar, E.; Fraga, M.F.; Cerrato, C.; Setien, F.; Casado, S.; Suarez-Gauthier, A.; Sanchez-Cespedes, M.; Git, A.; et al. Genetic unmasking of an epigenetically silenced microRNA in human cancer cells. Cancer Res. 2007, 67, 1424-1429. [CrossRef] [PubMed]

256. Saito, Y.; Liang, G.; Egger, G.; Friedman, J.M.; Chuang, J.C.; Coetzee, G.A.; Jones, P.A. Specific activation of microRNA-127 with downregulation of the proto-oncogene bcl6 by chromatin-modifying drugs in human cancer cells. Cancer Cell 2006, 9, 435-443. [CrossRef] [PubMed]

257. Fabbri, M.; Calin, G.A. Epigenetics and miRNAs in human cancer. Adv. Genet. 2010, 70, 87-99. [PubMed]

(C) 2015 by the authors; licensee MDPI, Basel, Switzerland. This article is an open access article distributed under the terms and conditions of the Creative Commons by Attribution (CC-BY) license (http://creativecommons.org/licenses/by/4.0/). 